\title{
A pollen-based biome reconstruction over the last 3.562 million years in the Far East Russian Arctic - new insights into climate-vegetation relationships at the regional scale
}

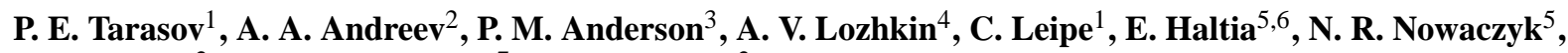 \\ V. Wennrich ${ }^{2}$, J. Brigham-Grette ${ }^{7}$, and M. Melles ${ }^{2}$ \\ ${ }^{1}$ Institute of Geological Sciences, Palaeontology Section, Free University Berlin, Malteserstr. 74-100, Haus D, \\ 12249 Berlin, Germany \\ ${ }^{2}$ Institute of Geology and Mineralogy, University of Cologne, Zülpicher Str. 49a, 50674 Cologne, Germany \\ ${ }^{3}$ Earth \& Space Sciences and Quaternary Research Center, University of Washington, Seattle, WA 98195-1310, USA \\ ${ }^{4}$ Northeast Interdisciplinary Scientific Research Institute, Far East Branch, Russian Academy of Sciences, 16 Portovaya St., \\ Magadan, 685000, Russia \\ ${ }^{5}$ Helmholtz Centre Potsdam, GFZ German Research Centre for Geosciences, Section 5.2 - Climate Dynamics and Landscape \\ Evolution, Telegrafenberg, 14473 Potsdam, Germany \\ ${ }^{6}$ Department of Geology, Lund University, Sölvegatan 12, 22362 Lund, Sweden \\ ${ }^{7}$ Department of Geosciences, University of Massachusetts, 611 North Pleasant St., Amherst, MA 01003, USA
}

Correspondence to: P. E. Tarasov (ptarasov@zedat.fu-berlin.de,paveltarasov@mail.ru)

Received: 13 May 2013 - Published in Clim. Past Discuss.: 25 June 2013

Revised: 24 October 2013 - Accepted: 11 November 2013 - Published: 12 December 2013

\begin{abstract}
The recent and fossil pollen data obtained under the frame of the multi-disciplinary international El'gygytgyn Drilling Project represent a unique archive, which allows the testing of a range of pollen-based reconstruction approaches and the deciphering of changes in the regional vegetation and climate. In the current study we provide details of the biome reconstruction method applied to the late Pliocene and Quaternary pollen records from Lake El'gygytgyn. All terrestrial pollen taxa identified in the spectra from Lake El'gygytgyn were assigned to major vegetation types (biomes), which today occur near the lake and in the broader region of eastern and northern Asia and, thus, could be potentially present in this region during the past. When applied to the pollen spectra from the middle Pleistocene to present, the method suggests (1) a predominance of tundra during the Holocene, (2) a short interval during the marine isotope stage (MIS) 5.5 interglacial distinguished by cold deciduous forest, and (3) long phases of taiga dominance during MIS 31 and, particularly, MIS 11.3. These two latter interglacials seem to be some of the longest and warmest intervals in the study region within the past million years.
\end{abstract}

During the late Pliocene-early Pleistocene interval (i.e., $\sim 3.562-2.200 \mathrm{Ma}$ ), there is good correspondence between the millennial-scale vegetation changes documented in the Lake El'gygytgyn record and the alternation of cold and warm marine isotope stages, which reflect changes in the global ice volume and sea level. The biome reconstruction demonstrates changes in the regional vegetation from generally warmer/wetter environments of the earlier (i.e., Pliocene) interval towards colder/drier environments of the Pleistocene. The reconstruction indicates that the taxon-rich cool mixed and cool conifer forest biomes are mostly characteristic of the time prior to MIS G16, whereas the tundra biome becomes a prominent feature starting from MIS G6. These results consistently indicate that the study region supported significant tree populations during most of the interval prior to $\sim 2.730 \mathrm{Ma}$. The cold- and drought-tolerant steppe biome first appears in the reconstruction $\sim 3.298 \mathrm{Ma}$ during the tundra-dominated MIS M2, whereas the tundra biome initially occurs between $\sim 3.379$ and $\sim 3.378$ Ma within MIS MG4. Prior to $\sim 2.800 \mathrm{Ma}$, several other cold stages during 
this generally warm Pliocene interval were characterized by the tundra biome.

\section{Introduction}

Since the introduction of pollen analysis to the field of geology in 1916, its main purpose has been the objective reconstruction of temporal and spatial changes in vegetation (mainly during the Quaternary period) at local to regional scales (Faegri and Iversen, 1989). Related to this task is the evaluation of the possible roles played by natural factors (e.g., climate change, volcanism, sea-level fluctuations) and/or by human activities (e.g., anthropogenic fires, wood cutting, and land use) in affecting the paleovegetation. The fact that the Arctic is poorly populated and human impact on high-latitude vegetation remains virtually insignificant, at least until very recently, makes pollen records from these regions an important source of information concerning the natural factors driving vegetation changes, particularly as related to centennial- and millennial-scale climate variability.

Sediment cores from Lake El'gygytgyn (Fig. 1) in northern Far East Russia provide a nearly continuous, highresolution environmental record from the Arctic, a record that spans the past $\sim 3.58 \mathrm{Myr}$ (Melles et al., 2012). Melles et al. (2012) and Brigham-Grette et al. (2013) have presented in summary form results of the multi-disciplinary studies of the Lz1024 and 5011-1 (International Continental Scientific Drilling Program - ICDP - Site 5011-1) sediment cores recovered from the central part of the lake (Fig. 1b). Among the analyzed proxies, results of the pollen analysis have been presented and used to reconstruct changes in the regional climate through the four Quaternary interglacial intervals, representing marine isotopic stage (MIS) 1, MIS 5, MIS 11 and MIS 31 (Melles et al., 2012; for the MIS 1 to MIS 8 interval, see also Lozhkin et al., 2007), and during the late Pliocene to early Pleistocene interval between $\sim 3.58$ and $\sim 2.2 \mathrm{Ma}$ (Brigham-Grette et al., 2013) by applying the best modern analog (BMA) approach (Overpeck et al., 1985; Guiot, 1990; Tarasov et al., 2005). Qualitative or quantitative interpretations of past environments can be challenging, especially during times when modern analogs are weak or nonexistent. However, the expansion of modern data sets and development of more sophisticated models and statistical treatment of the data over the past 2 decades facilitate the comparison of results from multiple approaches, particularly for reconstructing past climate and vegetation.

This paper presents the pollen-based biome reconstruction using the published late Pliocene and Quaternary pollen record from Lake El'gygytgyn and the "biomization" method first introduced by Prentice et al. (1996). The results are discussed in terms of the regional changes in vegetation and the bioclimatic variables controlling vegetation dynamics. The biome reconstruction is also compared with the published
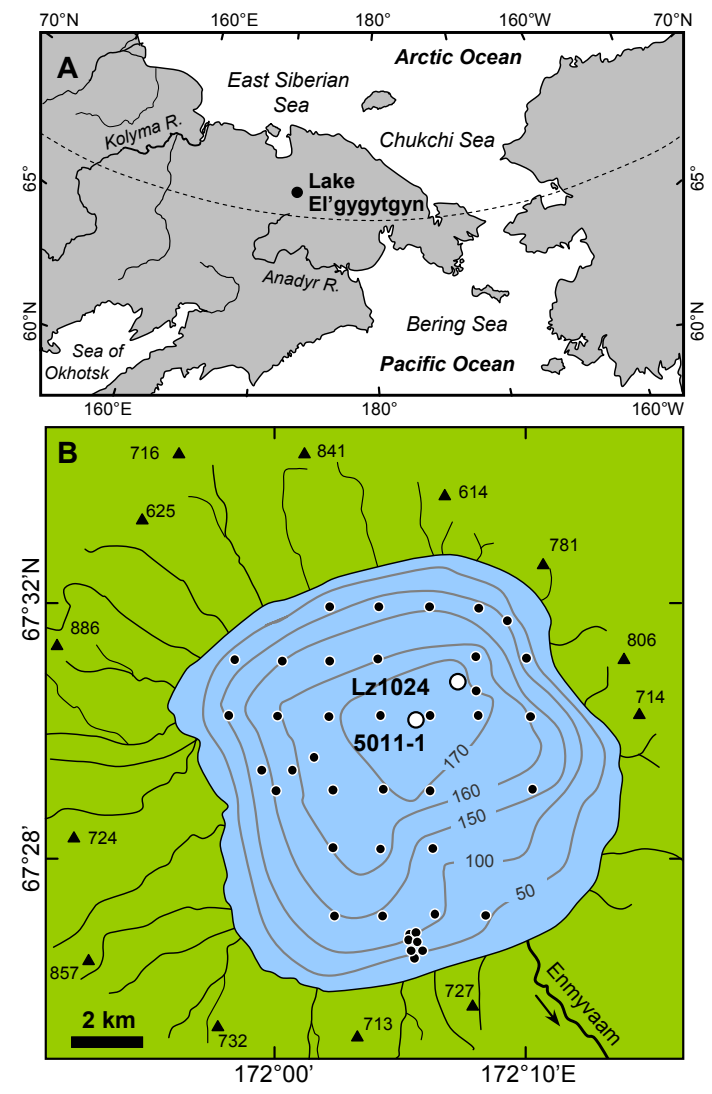

Fig. 1. Maps showing (A) geographical location of Lake El'gygytgyn (black dot; $67^{\circ} 30^{\prime} \mathrm{N}, 172^{\circ} 05^{\prime} \mathrm{E}$; $492 \mathrm{~m}$ a.s.1.) in northeastern Siberia; and (B) the catchment area of Lake El'gygytgyn with associated hydrological network. The lower map (B) also shows the locations of the modern pollen surface samples (closed circles) and fossil pollen records (open circles), bathymetric lines indicating lake water depth ( $\mathrm{m}$ below modern lake level), and highest mountain peaks (triangles accompanied with altitude values in ma.s.1.).

climate reconstruction using the BMA approach and with paleoclimate reconstructions based on other proxies than pollen, as well as with the published results of the climate and vegetation modeling.

\section{Data and method}

\section{$2.1 \quad$ Site setting}

Lake El'gygytgyn $\left(67^{\circ} 30^{\prime} \mathrm{N}, 172^{\circ} 05^{\prime} \mathrm{E} ; 492 \mathrm{~m}\right.$ a.s.1.) occupies the central part of a meteorite impact crater situated in the northeastern part of Asia, $\sim 100 \mathrm{~km}$ north of the northern polar circle, $\sim 265 \mathrm{~km}$ south of the East Siberian Sea and $\sim 390-420 \mathrm{~km}$ northwest of the Bering Sea (Fig. 1a). The impact occurred 3.58 $\pm 0.04 \mathrm{Myr}$ ago (Layer, 2000; see also Melles et al., 2012 and Vogel et al., 2013, for details on the regional geology). The lake has a roughly circular shape 
with a diameter of $12 \mathrm{~km}$ (Fig. 1b) and a maximum water depth of $175 \mathrm{~m}$ (Vogel et al., 2013). The lake surface area is about $110 \mathrm{~km}^{2}$, and the hydrological catchment area is about $293 \mathrm{~km}^{2}$ (Nolan and Brigham-Grette, 2007). The lake catchment area, limited by the crater's outer rim that has a maximum elevation of $857 \mathrm{~m}$ a.s.l. (Matrosova, 2009), is drained by numerous short and steep valleys with perennial creeks or ephemeral streams (Fig. 1b). The Enmyvaam River (Fig. 1b) flows from the southeastern part of the basin, connecting the lake with the Anadyr River system and the Bering Sea.

The regional climate is characterized by cold and long winters (September to May) with mean temperatures of the coldest month (MTCM) below $-32^{\circ} \mathrm{C}$, and short cool summers with mean temperatures of the warmest month (MTWM) less than $+9{ }^{\circ} \mathrm{C}$ according to the gridded $\left(10^{\prime} \times 10^{\prime}\right)$ global data set of modern climate averaged over a 30-yr (1961-1990) interval (New et al., 2002). The Russian sources (e.g., Treshnikov, 1985) provide even lower mean values, i.e., ranging between -32 and $-36^{\circ} \mathrm{C}$ in January and between +4 and $+8^{\circ} \mathrm{C}$ in July, though for a different observation period. The mean annual precipitation (PANN) at Lake El'gygytgyn is $\sim 250 \mathrm{~mm}$ (New et al., 2002). The relatively low PANN is not a limiting factor for plant growth, as evaporation losses are also low. Snow cover is up to $0.3-0.5 \mathrm{~m}$. This is greater than the minimum snow depth of $15 \mathrm{~cm}$ required to support growth of perennial cold shrubs (Kaplan et al., 2003). However, low MTWM prevents the establishment of boreal trees, which require MTWM values of at least $+11^{\circ} \mathrm{C}$ (e.g., MacDonald et al., 2000; Tarasov et al., 2013). Reflecting the modern regional climate, the vegetation of the Chukchi Uplands, which surrounds Lake El'gygytgyn, belongs to the southern shrub tundra and typical tundra zone (Yurtsev, 1974; Alpat'ev et al., 1976), although vegetation within the lake catchment is dominated by herb-lichen tundra. The upland area is characterized by grasses and sedges and moss tundra communities with occasional shrub thickets of alder (Alnus viridis subsp. fruticosa, also known as Duschekia fruticosa), willow (Salix) and birch (Betula) (e.g., Matrosova, 2009; see also Lozhkin and Anderson, 2013, and Andreev et al., 2013, for further details and references). Larch (Larix gmelinii) and dwarf stone pine (Pinus pumila) grow south and west of the lake within the forest-tundra and northern taiga zone. However tree line is located $\sim 150 \mathrm{~km}$ to the southwest of the lake (Lozhkin and Anderson, 2013).

\subsection{Pollen data and chronology}

The pollen data used in the current study include 43 modern pollen spectra representing (1) top samples of the short sediment cores (the upper $1 \mathrm{~cm}$ layer was analyzed; this interval may span up to 100-300 yr, according to the age models) recovered from Lake El'gygytgyn (Matrosova, 2009; Fig. 1b); and (2) published fossil pollen records, which represent the two sediment cores Lz1024 and 5011-1 recovered in the deepest central part of the lake (Fig. 1b). The pollen data for MIS 1 and MIS 5 interglacial intervals are from core Lz1024, whereas core 5011-1 provided samples from MIS 11 and MIS 31 (for detailed results of the pollen analysis and respective pollen diagrams, see Lozhkin et al., 2007; Melles et al., 2012; Lozhkin and Anderson, 2013). The pollen spectra from the lower part of core 5011-1 represent the late Pliocene and early Pleistocene interval between $\sim 3.58$ and $2.2 \mathrm{Ma}$ (for details of the pollen analysis and pollen diagrams, see Brigham-Grette et al., 2013, and Andreev et al., 2013). The fossil pollen data used for the biome reconstruction in the current study also have been the basis for recently reported quantitative climate reconstruction (for the core descriptions, see Melles et al., 2012, and Brigham-Grette et al., 2013).

The age model for the ICDP-Site 5011-1 sedimentary composite record was developed in several steps, successively refining the model. Initial tie points for the age model were provided from magnetostratigraphic investigation of the cores from ICDP Site 5011-1 (Haltia and Nowaczyk, 2013), defining the positions of major geomagnetic reversals back to the early Gauss chron. The age of the El'gygytgyn impact at $3.58 \pm 0.04 \mathrm{Ma}$ (Layer, 2000) provided another initial tie point. Additional tie points could be derived from fine-tuning of various climatically controlled sedimentological and geochemical parameters (biogenic silica, total organic carbon (TOC), tree and shrub pollen percentages, grain size analyses, sediment color, $\mathrm{Si} / \mathrm{Ti}$ ratio obtained from Xray fluorescence (XRF) scanning, magnetic susceptibility) to both the marine oxygen isotope stack (LR04) of Lisiecki and Raymo (2005) and the Northern Hemisphere summer insolation provided by Laskar et at. (2004) (for further details, see Nowaczyk et al., 2013).

\subsection{Biome reconstruction method}

Pollen-based biome reconstructions using the numerical method of Prentice et al. (1996) provide new insights into past vegetation dynamics and facilitate data-model comparison. The latter is possible thanks to the use of the same concepts of biome definition in the pollen-based biome reconstructions and climate-based biome simulations (Prentice et al., 1996; Kaplan, 2001). The "biomization" approach was developed in order to produce global vegetation maps for the Last Glacial Maximum and for middle Holocene time slices - a major task of the BIOME 6000 Project (Prentice and Webb III, 1998). Since then, the method has become rather popular and has been applied to the fossil pollen records from different regions and with results published in numerous journals. The main use of the biome reconstruction method initially was limited to the aims of the BIOME 6000 Project (i.e., obtaining information on the dominant natural vegetation types). However, this does not mean that the method has no further potential. Other studies (i.e., Peyron et al., 1998; Guiot et al., 1999; Williams et al., 2004; Gotanda et al., 2008; Rudaya et al., 2009; Müller et al., 2010) demonstrate 
a broader range of applications that use quantitative results of biome/PFT score calculations. Examining all biome affinity scores (and not only deriving the dominant biome name) throughout a pollen record for more objective interpretation of reconstruction results has been presented in various papers published elsewhere (i.e., Tarasov et al., 1997, 2013; Marchant et al., 2002, 2006; Rudaya et al., 2009).

In the biome reconstruction approach, pollen taxa are assigned to plant functional types (PFTs) and to principal vegetation types (biomes) on the basis of the modern ecology, bioclimatic tolerance, and spatial distribution of the pollen-producing plants. The method initially was tested using global-scale modern pollen data sets (e.g., Prentice et al., 1996, 2000), but further modifications of the biome-taxa matrixes (i.e., "tuning" of the biomization approach for the regional conditions) were developed for large parts of Siberia and Alaska (e.g., Tarasov et al., 1998; Edwards et al., 2000). A successful validation of the method using modern pollenvegetation-climate data encouraged an application of the approach to data sets from the mid-Holocene, Last Glacial Maximum, and last interglacial in areas of northern Eurasia and North America (Edwards et al., 2000; Tarasov et al., $2000,2005)$. Concerns relating to the ability of the method to differentiate cold deciduous forest, taiga, and tundra in these earlier studies (see also Müller et al., 2009) resulted in further testing of the method using a modern pollen data set from Yakutia (Müller et al., 2010). Based on the results of this study, several modifications (mainly concerning tree and shrub forms of Betula and Alnus/Duschekia that represent a wide range of regional vegetation types) were made in the biome-taxon matrix. The modified scheme became more consistent with the authors' field observations, regional botanical studies (Müller et al., 2010, and references therein), and with the taxa to biome attribution suggested for northeastern Siberia (i.e., Edwards et al., 2000; Anderson et al., 2002).

The biome-taxon matrix (Table 1) used in the current study employs the taxa-to-biome attribution published by Müller et al. (2010). However, their matrix does not include all terrestrial pollen taxa that have been identified in the sediment samples from Lake El'gygytgyn dated to the late Pliocene and early and middle Pleistocene (Andreev et al., 2013; Brigham-Grette et al., 2013; Lozhkin and Anderson, 2013). These taxa, including Carpinus (hornbeam), Carya (hickory), Corylus (hazel), Juglans (walnut), Pterocarya (wingnut), deciduous Quercus (oak), Tilia (lime), Ulmus (elm), and Tsuga (hemlock), represent warmer vegetation types (i.e., cool conifer forest, cool mixed forest and temperate deciduous forest) that did not grow in the northern and northeastern parts of Asia under the extremely cold and continental climate conditions of the late Quaternary, but possibly occurred in the region close to Lake El'gygytgyn during the earlier, much warmer than present intervals (Brigham-Grette et al., 2013). In order to consider the whole range of the Lake El'gygytgyn pollen taxa and less continental boreal and temperate forest biomes that appear in the modern vegetation of the southern Russian Far East (e.g., Mokhova et al., 2009), northern Japan (e.g., Takahara et al., 2010) and China (e.g., Yu et al., 1998), the biome-taxon matrix applied here (Table 1) was extended using the published matrixes tested with the surface modern pollen data from the respective regions of Asia (Yu et al., 2000; Mokhova et al., 2009; Tarasov et al., 2011).

The biome score calculation was performed using the standard equation and reconstruction procedures described in Prentice et al. (1996) and the PPPBase software developed by Guiot and Goeury (1996). The sum of all terrestrial pollen taxa (Table 1) identified in the Lake El'gygytgyn records was taken as $100 \%$ for calculating the percentages of an individual taxon.

As suggested by Prentice et al. (1996) and accepted in the global vegetation mapping BIOME 6000 Project (Prentice and Webb III, 1998), square root transformation was applied to the pollen percentage values. This operation stabilizes variance and increases the method's sensitivity to less abundant taxa (Overpeck et al., 1985). The $0.5 \%$ threshold was applied to all pollen taxa, as recommended by Prentice et al. (1996) in order to minimize possible noise due to long-distance transport, re-deposition and misidentification of single grains representing extremely rare taxa. Edwards et al. (2000) applied a weighting $(\times 20)$ to occurrences of Larix in individual pollen spectra, in order to maximize the chance of reconstructing cold deciduous forest when it was probably present. We did not weight Larix percentages in the current study (for discussion of the different approaches, see Müller et al., 2010).

The biome reconstruction method is based on a fuzzy logic approach, in which each pollen sample is estimated to have a numerical "affinity" with every potential biome listed in Table 1. The final biome identification is based on ranking the affinity scores (Prentice et al., 1996). The biome with the highest affinity score or the one defined by a smaller number of taxa/PFTs (when scores of several biomes are equal) is treated as the biome that dominated the area during the time of deposition of the analyzed pollen spectrum.

In order to distinguish the cold steppe biome from the warm steppe biome, the presence of boreal trees and the presence of arctic-alpine shrub taxa are used as additional criteria to assign herbaceous pollen taxa to the appropriate biome. This distinction is based on the reasonable assumption that the temperature requirements of the herbaceous taxa may be indicated by associated tree and shrub pollen taxa that can be identified to a lower taxonomic level than herbs (full details are presented in Tarasov et al., 1998).

The biomization approach provides no quantitative information about vegetation composition or structure and can mask temporal variations in the internal structure and composition of biomes (Williams et al., 2004). It also does not allow the reconstruction of transitional vegetation types, e.g., forest-steppe, tundra-steppe, and forest-tundra (Prentice et 
Table 1. Biome-taxon matrix used in the biome reconstruction. All terrestrial pollen taxa identified in the fossil pollen spectra in the Lake El'gygytgyn record are attributed to one or several biomes.

\begin{tabular}{|c|c|c|}
\hline $\begin{array}{l}\text { Biome name/ } \\
\text { abbreviation }\end{array}$ & $\begin{array}{l}\text { Biome } \\
\text { order }\end{array}$ & Attributed pollen taxa \\
\hline Tundra/TUND & 1 & $\begin{array}{l}\text { Alnus fruticosa-type (shrub), Betula sect. Albae-type (tree), B. sect. } \\
\text { Nanae-type (shrub), B. undif., Cyperaceae, Ericales, Poaceae, Polemoniaceae, } \\
\text { Polygonum bistorta-type, Rubus chamaemorus, Rumex, Salix, } \\
\text { Saxifragaceae, Valerianaceae }\end{array}$ \\
\hline $\begin{array}{l}\text { Cold deciduous } \\
\text { forest/CLDE }\end{array}$ & 2 & $\begin{array}{l}\text { Alnus fruticosa-type (shrub), A. sp. (tree), Betula sect. Albae-type (tree), B. } \\
\text { sect. Nanae-type (shrub), B. undif., Cupressaceae/Taxodiaceae, Ericales, } \\
\text { Larix/Pseudotsuga, Pinus subgenus Diploxylon, P. subgenus Haploxylon, } \\
\text { Pinaceae undif., Populus, Rubus chamaemorus, Salix }\end{array}$ \\
\hline Taiga/TAIG & 3 & $\begin{array}{l}\text { Abies, Alnus sp. (tree), Betula sect. Albae-type (tree), B. sect. Nanae-type } \\
\text { (shrub), B. undif., Cupressaceae/Taxodiaceae, Ericales, Larix/Pseudotsuga, } \\
\text { Lonicera, Picea, Pinus subgenus Diploxylon, P. subgenus Haploxylon, } \\
\text { Pinaceae undif., Populus, Rubus chamaemorus, Salix }\end{array}$ \\
\hline $\begin{array}{l}\text { Cool conifer } \\
\text { forest/COCO }\end{array}$ & 4 & $\begin{array}{l}\text { Abies, Alnus sp. (tree), Betula sect. Albae-type (tree), B. sect. Nanae-type } \\
\text { (shrub), B. undif., Carpinus-type, Corylus, Cupressaceae/Taxodiaceae, } \\
\text { Ericales, Larix/Pseudotsuga, Lonicera, Picea, Pinus subgenus Diploxylon, } \\
\text { P. subgenus Haploxylon, Pinaceae undif., Populus, Salix, Tilia, Tsuga, Ulmus }\end{array}$ \\
\hline $\begin{array}{l}\text { Temperate } \\
\text { deciduous } \\
\text { forest/TEDE }\end{array}$ & 5 & $\begin{array}{l}\text { Abies, Alnus sp. (tree), Betula sect. Albae-type (tree), B. sect. Nanae-type } \\
\text { (shrub), Betula undif., Carpinus-type, Carya, Corylus, } \\
\text { Cupressaceae/Taxodiaceae, Ericales, Juglans, Larix/Pseudotsuga, Lonicera } \\
\text {-type, Pinus subgenus Diploxylon, Pinaceae undif., Populus, Pterocarya, } \\
\text { Quercus deciduous, Salix, Tilia, Ulmus }\end{array}$ \\
\hline $\begin{array}{l}\text { Cool mixed } \\
\text { forest/COMX }\end{array}$ & 6 & $\begin{array}{l}\text { Abies, Alnus sp. (tree), Betula sect. Albae-type (tree), B. sect. Nanae-type } \\
\text { (shrub), B. undif., Carpinus-type, Corylus, Cupressaceae/Taxodiaceae, } \\
\text { Ericales, Larix/Pseudotsuga, Lonicera-type, Picea, Pinus subgenus } \\
\text { Diploxylon, P. subgenus Haploxylon, Pinaceae undif., Populus, Tsuga, } \\
\text { Quercus deciduous, Salix, Tilia, Ulmus }\end{array}$ \\
\hline $\begin{array}{l}\text { Warm mixed } \\
\text { forest/WAMX }\end{array}$ & 7 & $\begin{array}{l}\text { Alnus sp. (tree), Carpinus-type, Carya, Corylus, Cupressaceae/Taxodiaceae, } \\
\text { Ericales, Juglans, Lonicera, Pinus subgenus Diploxylon, Pinaceae undif., } \\
\text { Populus, Pterocarya, Quercus deciduous, Salix, Tilia, Ulmus }\end{array}$ \\
\hline $\begin{array}{l}\text { Cold } \\
\text { steppe/STEP }\end{array}$ & 8 & $\begin{array}{l}\text { Apiaceae, Artemisia, Asteraceae Asteroideae, Asteraceae Cichorioideae, } \\
\text { Brassicaceae, Cannabis-type, Caryophyllaceae, Chenopodiaceae, Fabaceae, } \\
\text { Lamiaceae, Linum, Onagraceae, Papaveraceae, Plantaginaceae, Poaceae, } \\
\text { Polygonum bistorta-type, Ranunculaceae, Rosaceae, Rumex, Sanguisorba, } \\
\text { Thalictrum, Urticaceae, Valerianaceae }\end{array}$ \\
\hline
\end{tabular}

al., 1996). However, this missing information can be partly recovered by examining the relative values of the dominant and co-dominant biome scores (e.g., Tarasov et al., 2000; Fig. 2b). Additional qualitative information concerning the vegetation cover (i.e., landscape openness) can be obtained by calculating the difference between the maximum forest biomes score (MFBS) and the maximum open biomes score (MOBS) for the analyzed pollen assemblages (e.g., Fig. 3c).

In order to check how best to infer past extent of woody vegetation in the study region, we compared percentages of trees and shrubs and biome-score-based landscape openness calculated from the modern pollen spectra in northern
Asia with the satellite-based values of woody cover around the modern pollen-sampling sites (calculation details are explained in Tarasov et al., 2007b and Williams et al., 2011). The arboreal pollen percentages, biome-derived landscape openness, and satellite-derived woody cover from two macro-regions of Eurasia, namely "Central Eurasia Region (CER)" (ca. $40-70^{\circ} \mathrm{N}, 30-120^{\circ} \mathrm{E}$ ) and "Russian Far East Region (RFER)" (47-63 $\left.\mathrm{N}, 132-152^{\circ} \mathrm{E}\right)$, were compared. The results of these tests clearly demonstrate a stronger correlation between satellite-derived (actual) woody cover and biome-score-derived openness (calculated as in current manuscript) in both regions (i.e., correlation coefficient 0.76 


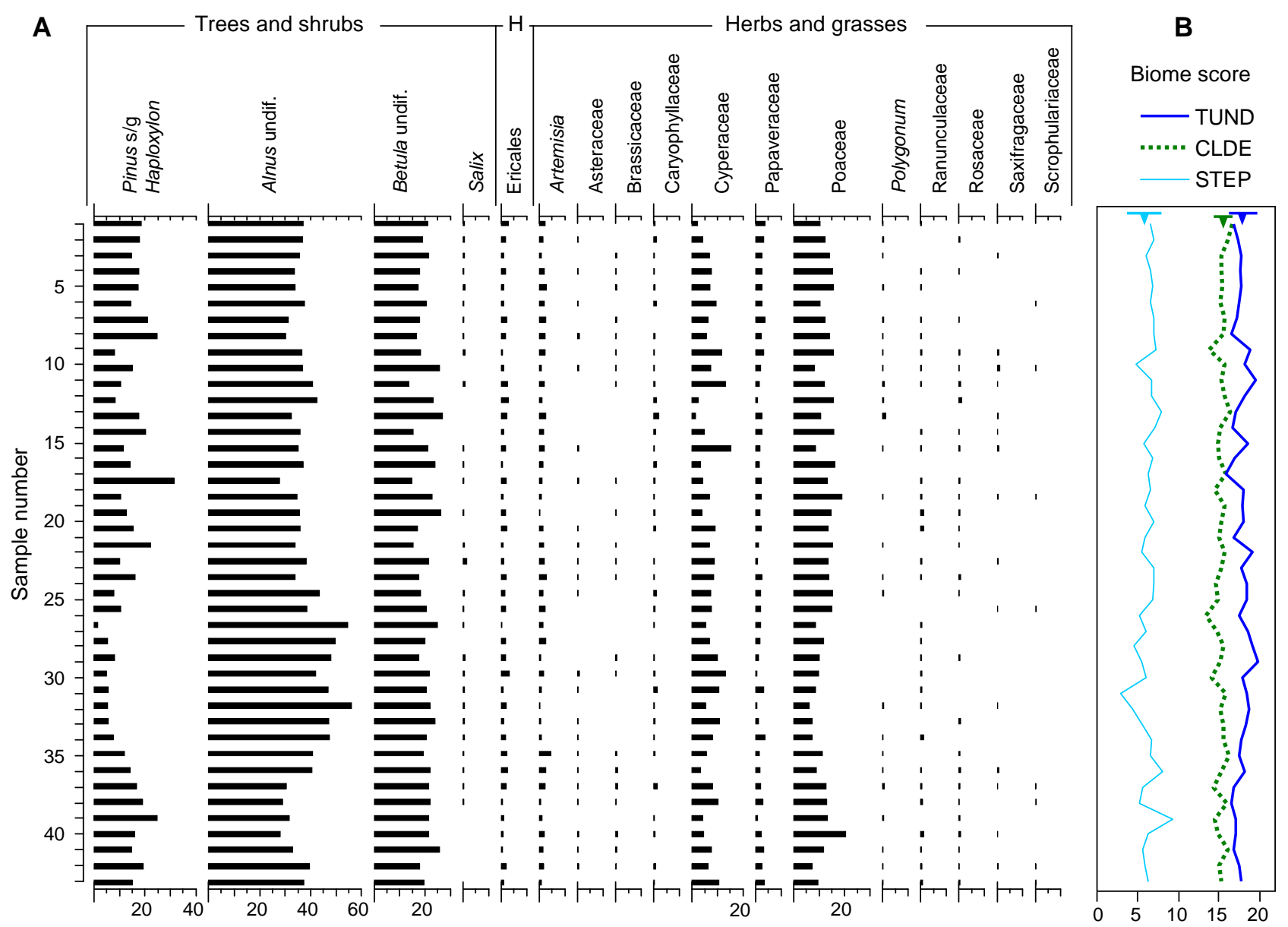

Fig. 2. Diagram of modern data from Lake El'gygytgyn: (A) summary pollen percentage diagram of the 43 modern surface pollen spectra (pollen analyst T. Matrosova), and (B) calculated affinity scores of individual biomes that dominated in the study area during the late Quaternary. Triangles indicate the modern mean score value of each respective biome, and horizontal bars indicate the $95 \%$ uncertainty ranges ( 2 standard deviations away from the mean). The diagram was constructed using Tilia/Tilia-Graph/TGView software (Grimm, 1993, 2004). Percentages for individual terrestrial pollen taxa at each level were calculated from the sum of arboreal and non-arboreal pollen. Only taxa that exceed the $0.5 \%$ threshold are shown. $H$ indicates heath. Biome names are abbreviated as follows: STEP - cold steppe, TUND tundra, and CLDE - cold deciduous forest.

in CER and 0.88 in RFER) and substantially weaker correlation between satellite-derived woody cover and woody pollen percentages (i.e., 0.55 in CER and 0.56 in RFER). The reason for this difference is partly explained by Prentice et al. (1996). Biome score calculation accounts for the ecology of pollen-producing plants and does not entirely rely upon a statistical similarity between pollen assemblages composed of numerous taxa representing ecologically different plant functional types (Bezrukova et al., 2010). The additional results obtained with the modern data sets from the study region justify the methodological approach applied in the current study. Once more we would like to stress that biome scores are used as qualitative indicators of climatic-driven trends in the vegetation development rather than quantitative (i.e., percentage) estimates of woody cover or biome-covered area in the study region.

\section{Results and discussion}

\subsection{Test with the modern pollen spectra}

All 43 pollen assemblages from the surface sediments of Lake El'gygytgyn (Matrosova, 2009) show that only 17 terrestrial pollen taxa exceed the $0.5 \%$ threshold and influence the biome score calculation (Fig. 2a). All assemblages are dominated by Alnus, Betula and Pinus subg. Haploxylon pollen, representing regional alder, birch and pine shrubs, respectively. Poaceae (grasses) and Cyperaceae (sedges) are the most common herbaceous pollen taxa, and reflect local and regional graminoid tundra. These modern pollen assemblages support the conclusion that the pollen rain in Lake El'gygytgyn is more indicative of regional than local catchment vegetation with up to $60 \%$ of the pollen (Alnus, Betula, Pinus pumila) coming from the surrounding 


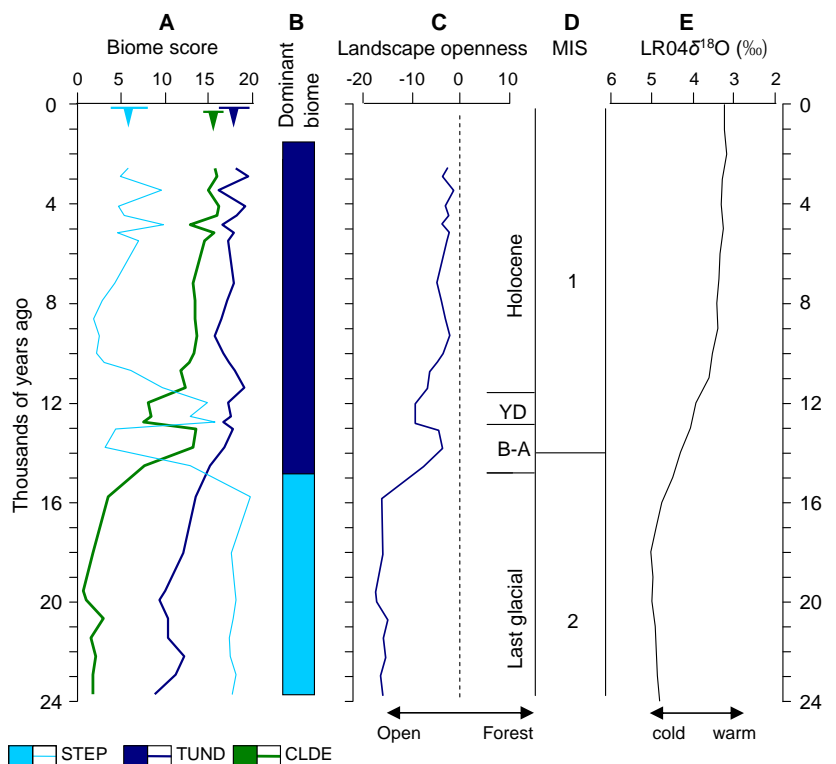

Fig. 3. Summary diagram for the last $\sim 24$ ka showing the (A) time series of individual biomes (triangles indicate the modern mean score of each respective biome; horizontal bars indicate the $95 \%$ uncertainty ranges); (B) dominant biomes; (C) characteristic of landscape openness calculated as the difference between the maximum score of forest biomes (MSFB) and the maximum score of open biomes (MSOB) at each level; and (D) marine isotope stage (MIS) boundaries and (E) stack of 57 globally distributed benthic $\delta^{18} \mathrm{O}$ records (after Lisiecki and Raymo, 2005). The Younger Dryas is indicated by $\mathrm{YD}$, and the $\mathrm{B} \varnothing l$ lling-Allerød is indicated by $\mathrm{B}-$ A. Biome names are abbreviated as follows: STEP - cold steppe, TUND - tundra, and CLDE - cold deciduous forest.

uplands (Lozhkin et al., 2001). This predominantly regional signal in the modern pollen assemblages strengthens the use of the Lake El'gygytgyn pollen data for palaeoclimatic interpretations (Lozhkin et al., 2007; Melles et al., 2012; Brigham-Grette et al., 2013) and vegetation reconstructions (Brigham-Grette et al., 2013; Lozhkin and Anderson, 2013).

The biome reconstruction (Fig. 2b) identifies the tundra (TUND) as having the highest affinity scores, and reflects well the regional vegetation in northern Chukotka. A test of the biomization approach using the set of surface pollen assemblages from Lake El'gygytgyn (Fig. 2b) provides additional important information on the uncertainty in the biomization procedure. The variation (standard deviation) of the biome scores therefore could be potentially used to represent the uncertainty of any single down-core biome score, at least those from interglacial periods. The $95 \%$ ranges (2 standard deviations away from the surface samples mean) calculated for the TUND, cold deciduous forest (CLDE) and cold steppe (STEP) biome scores have been added to Fig. 2b and to Figs. 3a, 4a, 5a and 6a for comparison.

\subsection{The last glacial and Holocene interval $(\sim 24-2 \mathrm{ka}$ ago)}

The results of biomization (Fig. 3) show that the STEP vegetation type displays the highest affinity scores during the last glacial $\sim 24-16 \mathrm{ka}$ ago (Fig. 3a) and remains dominant prior to $\sim 14.9 \mathrm{ka}$ ago (Fig. $3 \mathrm{~b}$ ). This vegetation reconstruction suggests that drought- and cold-tolerant herbaceous communities played a major role in the regional vegetation cover. TUND biome scores for the glacial assemblages are substantially lower than in the modern pollen spectra, and the CLDE scores are at minimum, reflecting virtual absence of tree and shrub vegetation in the glacial landscape (Fig. 3c). The interval after $\sim 16 \mathrm{ka}$ ago experiences drastic changes in the biome composition. The Bølling-Allerød (B-A) interstadial (Fig. 3) is characterized by a marked increase in the TUND and CLDE scores and is accompanied by a decrease in the STEP scores, the latter to almost present-day levels. The Younger Dryas (YD) chronozone shows biome scores that broadly resemble values reconstructed for the full glacial. The TUND biome remains dominant, suggesting that YD conditions were less severe than during the interval prior to $14.9 \mathrm{ka}$ ago. The Holocene is characterized by a continuous dominance of TUND. Between $\sim 10.5$ and $8 \mathrm{ka}$ ago, STEP reveals its lowest scores for the entire record. This interval likely corresponds to the early Holocene climatic optimum. Despite a marked increase in CLDE scores, the biome reconstruction suggests that the Holocene landscape remained generally open and that trees did not play an important role in the regional vegetation (Fig. 3c).

High percentages of Betula and Alnus characterize the late glacial and early Holocene pollen record from Lake El'gygytgyn (Lozhkin et al., 2007). Depending on climatic and ecological conditions, both taxa (and Salix) may have substantially different life forms that may also represent different biomes. As arctic-alpine shrubs and dwarf shrubs, these taxa are characteristic of the tundra biome, whereas when occurring as tall shrubs and trees they are important constituents of several boreal and boreal-temperate forest biomes (Table 1). Unfortunately, pollen grains representing tree and shrub forms of the same taxon have little morphological difference. This morphological similarity often prevents pollen analysts from distinguishing between the two forms and challenges pollen-based vegetation and climate reconstructions (Prentice et al., 1996). Therefore, our biomization scheme uses a conservative approach and assigns Alnus and Betula to both TUND and CLDE biomes. Despite these potential limitations, Andreev et al. (2012), who analyzed several Holocene permafrost sequences in the vicinity of Lake El'gygytgyn, assigned pollen of Alnus and Betula mainly to their shrub forms. Their results indicate the presence of tundra and forest-tundra communities and thus support the conclusions drawn from the biome reconstructions. However, macrofossil analysis of an organic-rich deposit, dated to $\sim 9100-8100{ }^{14} \mathrm{C}$ yr BP and located $\sim 1 \mathrm{~km}$ away from 
Lake El'gygytgyn, revealed larch needles, tree-sized alder, and taxa that today are restricted to areas to the south of the lake (Shilo et al., 2008). Moreover, larch seeds were found in the P2 core (Andreev et al., 2012) on the northern shore of Lake El'gygytgyn and dated to $9640 \pm 60{ }^{14} \mathrm{C}$ yr BP, indicating that larch grew in the lake crater during the early Holocene. Furthermore, macrofossil studies to the north of current tree line in Chukotka indicate that alder and willow achieved tree heights during the same interval (Lozhkin, 1993), suggesting, at least during the Holocene thermal maximum, cold deciduous woodland was likely present in areas of northern Chukotka.

Climate reconstructions of the early Holocene thermal maximum (Lozhkin et al., 2007) revealed mean July (i.e., MTWM) temperatures that were up to 2 to $4{ }^{\circ} \mathrm{C}$ warmer than present. Paleobotanical data suggest that the study area perhaps supported vegetation similar to high shrub tundra found today in southern Chukotka. Additionally, gallery birch and willow forests established in protected river valleys and possibly stands of deciduous trees occurred in sheltered areas within the interfluves (Edwards et al., 2005; Lozhkin and Anderson, 2013). More recent climate reconstructions using the BMA approach (Melles et al., 2012) also indicate a 2 to $4{ }^{\circ} \mathrm{C}$ increase in MTWA above the present-day level (within the reconstruction uncertainty range). The latter results suggest that the early Holocene warming in the study area was probably less pronounced (Melles et al., 2012) than suggested by Lozhkin et al. (2007) and that the more moderate temperatures would prevent significant forest development in the region.

Inspection of the biome score variability in Fig. $2 \mathrm{~b}$ suggests that the scores of tundra (mean value 17.68, 95\% uncertainty range 15.95-19.41) and cold deciduous forest (mean 15.19, 95\% uncertainty range 13.86-16.52) in the modern pollen spectra are not easily distinguishable from one another. This result of biomization helps to resolve the apparently contradictory result of high Holocene TUND biome scores in the presence of macrofossils of tree taxa.

\subsection{The penultimate glacial-interglacial transition and the last interglacial interval $(\sim 138-89$ ka ago $)$}

Biomization results (Fig. 4) show that STEP has the highest affinity scores at the end of the penultimate glacial $\sim 138$ $136 \mathrm{ka}$ ago (Fig. 4a). However, TUND becomes a dominant vegetation type after $\sim 135 \mathrm{ka}$ ago (Fig. $4 \mathrm{~b}$ ). The CLDE affinity scores show a marked increase by $\sim 133 \mathrm{ka}$ ago and a subsequent drop $\sim 130 \mathrm{ka}$ ago, resembling the abrupt climate reversal, as revealed during the late last glacial interval (i.e., the YD reversal in Fig. 3) and during the Termination III (i.e., Martrat et al., 2007; Cheng et al., 2009). The onset of interglacial conditions as indicated by the vegetation reconstruction (Fig. $4 \mathrm{c}$ ) can be placed $\sim 128 \mathrm{ka}$ ago, or just above the MIS 6/MIS 5 boundary (Fig. 4d). Although maximum CLDE scores are between $\sim 128$ and $115 \mathrm{ka}$ ago (MIS 5.5),

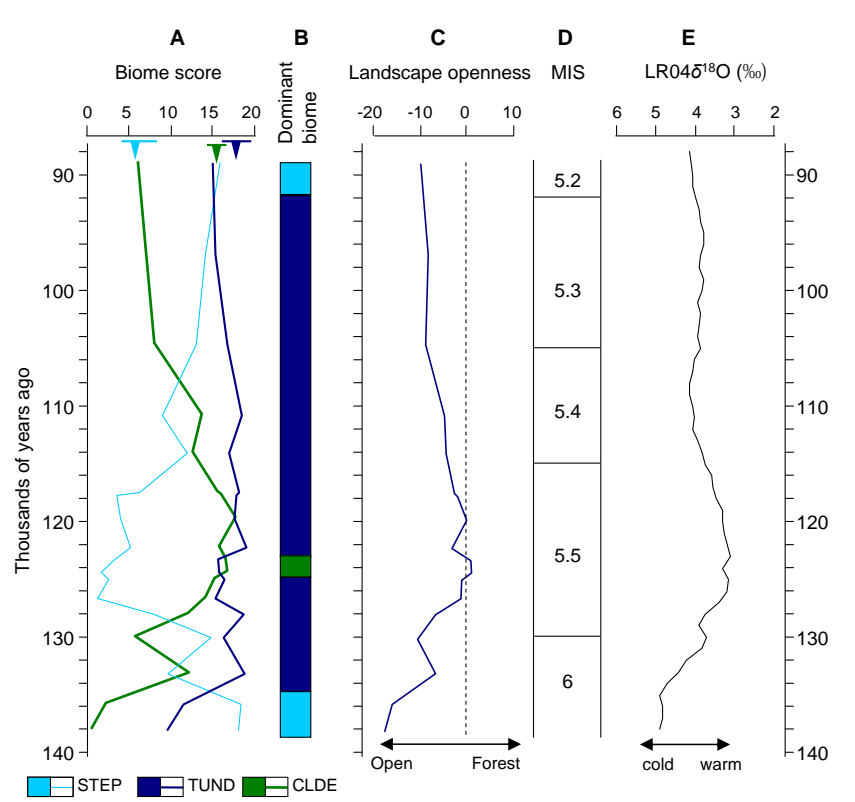

Fig. 4. Summary of paleoenvironmental trends between $\sim 138$ and $\sim 89$ ka ago showing the (A) time series of individual biomes (triangles indicate the modern mean score of each respective biome; horizontal bars indicate the $95 \%$ uncertainty ranges); (B) dominant biomes; (C) characteristic of landscape openness calculated as the difference between the maximum score of forest biomes (MSFB) and the maximum score of open biomes (MSOB) at each level; and (D) marine isotope stage (MIS) boundaries and (E) stack of 57 globally distributed benthic $\delta^{18} \mathrm{O}$ records (after Lisiecki and Raymo, 2005). Biome names are abbreviated as follows: STEP cold steppe, TUND - tundra, and CLDE - cold deciduous forest.

relatively high TUND scores suggest that this vegetation type was an important landscape element during most of the last interglacial interval. Two samples with CLDE scores slightly higher than those for TUND are dated to $\sim 125$ $123 \mathrm{ka}$ ago. STEP has its lowest scores for the whole record between $\sim 127$ and $123 \mathrm{ka}$ ago. All the evidence suggests this interval as the interglacial climatic optimum with the highest temperature and precipitation values, and the most extensive establishment of shrub-tundra and forest-tundra communities within the region. Although the biome scores (Fig. 4a) suggest that woody plants likely played a more important role in the regional vegetation during the last interglacial as compared to the Holocene, the biome reconstruction indicates that open vegetation predominates on the regional landscape (Fig. 4c). Starting from $\sim 115 \mathrm{ka}$ ago, the biome reconstruction demonstrates a progressive decrease in CLDE and synchronous increase in STEP scores, marking the interglacial-glacial transition. TUND scores remain important until $\sim 92 \mathrm{ka}$ ago, and STEP scores achieve their highest values after that, likely indicating the onset of the extremely cold and dry climate of the full glacial.

The pollen record of the MIS 5.5 climatic optimum from Lake El'gygytgyn (Lozhkin et al., 2007; Lozhkin and 
Anderson, 2013) shows high percentages of Betula and Alnus that, when combined with the other tree/shrub taxa, constitute over $95 \%$ of the pollen assemblage. The percentages of herbaceous taxa are substantially lower than those recorded in the Holocene assemblages. These characteristics suggest that the MIS 5.5 climate optimum was wetter and warmer than the Holocene maximum and that tree and shrub communities were more common in the regional vegetation (Lozhkin and Anderson, 2013). This interpretation agrees with the analog-based climate reconstructions (Lozhkin et al., 2007; Melles et al., 2012; Fig. 7c and d) and with the results of the biome reconstruction presented here (Fig. 4).

The expansion of trees in the study region during the MIS 5 climate optimum remains under debate. Although woody plant macrofossils assigned to the last interglacial have been found throughout the Siberian Arctic beyond modern tree line (Lozhkin and Anderson, 1995; Kienast et al., 2011, and references therein), chronological control at many sites is rather weak (Lozhkin and Anderson, 2013).

Evidence from the recently studied site Oyogos Yar $\left(72.68^{\circ} \mathrm{N}, 143.53^{\circ} \mathrm{E}\right)$ from northern Yakutia (Kienast et al., 2011) suggests that open forest-tundra with larch (Larix dahurica), tree alder (Alnus incana), and birch and alder shrubs, interspersed with patches of steppe and meadows, occupied the Yana-Indigirka lowland in the westernmost part of Beringia. The presence of larch indicates that tree line shifted at least $270 \mathrm{~km}$ north of its current position and that the MTWM exceeded $13^{\circ} \mathrm{C}$ during the last interglacial optimum (Kienast et al., 2011). The pollen-based climate reconstruction for Lake El'gygytgyn demonstrates a less pronounced increase in summer temperature (Melles et al., 2012) than inferred for Oyogos Yar, which is located $\sim 1200 \mathrm{~km}$ to the west of the lake. The temperature differences reconstructed for MIS 5.5 suggest that the central part of the Siberian Arctic perhaps experienced a stronger warming and a greater northward advance of tree line as compared to northeastern Siberia. A similar situation was noted during the Holocene (e.g., Texier et al., 1997; Binney et al., 2009, and references therein).

\subsection{The interval including the MIS 11 interglacial ( 428-356 ka ago)}

The biome reconstruction (Fig. 5) displays abrupt changes in the vegetation in the Lake El'gygytgyn region over the MIS 12/MIS 11 transition. The shift in dominance of full glacial steppe/tundra (STEP and TUND) to boreal taiga forest (TAIG) occurs within a rather short time interval $(\sim 428$ to $424 \mathrm{ka}$ ago; Fig. $5 \mathrm{a}$ and b). However, the biome reconstruction does not show an event similar to a YD-like oscillation, as seen during the MIS 2/1 (Fig. 3a) and MIS 6/5 (Fig. 4a) transitions. Unlike the two youngest interglacials (MIS 5.5 and MIS 1), the biome results suggest a long phase of TAIG dominance (Fig. 5b) with a major spread of woody vegetation in the study region occurring between $\sim 424$ and $399 \mathrm{ka}$

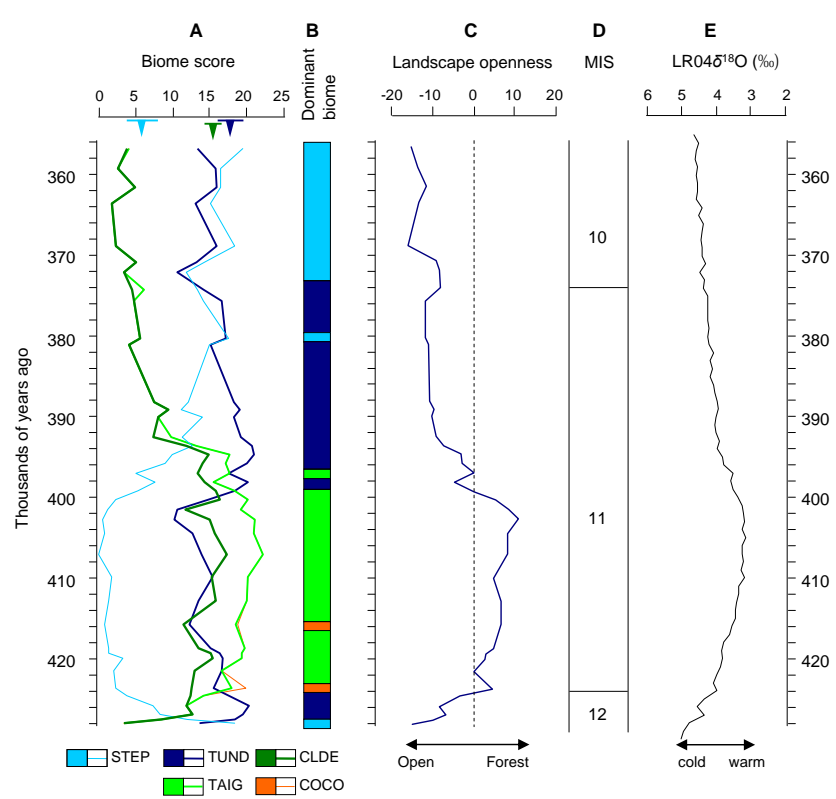

Fig. 5. Summary of paleoenvironmental trends between $\sim 428$ and $\sim 356$ ka ago showing the (A) time series of individual biomes (triangles indicate the modern mean score of each respective biome; horizontal bars indicate the $95 \%$ uncertainty ranges); (B) dominant biomes; $(\mathbf{C})$ characteristic of landscape openness calculated as the difference between the maximum score of forest biomes (MSFB) and the maximum score of open biomes (MSOB) at each level; and (D) marine isotope stage (MIS) boundaries and (E) stack of 57 globally distributed benthic $\delta^{18} \mathrm{O}$ records (after Lisiecki and Raymo, 2005). Biome names are abbreviated as follows: STEP cold steppe, TUND - tundra, CLDE - cold deciduous forest, TAIG - taiga, and COCO - cool conifer forest. Note that TAIG and COCO biomes are not present in the modern regional vegetation, and therefore their score is identical to CLDE in the modern spectra (see Prentice et al., 1996, and Sect. 2.3 for explanations).

ago (i.e., over $25 \mathrm{ka}$ ). The final stage of the MIS 11.3 interglacial (prior to $394 \mathrm{ka}$ ago) experienced abrupt increases in TUND and STEP scores with an associated decrease in the forest biomes scores. This pattern suggests a shift towards colder/drier environments $\sim 400 \mathrm{ka}$ ago. TUND becomes a dominant vegetation type during the remaining part of MIS 11 (Fig. 4b), while STEP shows highest values during MIS 10 between $\sim 374$ and $356 \mathrm{ka}$ ago. This shift in biome scores indicates a return to extremely cold and dry full glacial climate.

The MIS 11 pollen record differs substantially from those of MIS 1 and MIS 5 (Lozhkin and Anderson, 2013). In particular, the MIS 11 pollen assemblages contain high percentages of Picea (spruce) and significant amounts of Larix pollen, suggesting greater forestation of the region under conditions that were much warmer and wetter than present. The expansion of Picea to the Lake El'gygytgyn region is reflected in the dominance of the boreal evergreen conifer forest (i.e., TAIG) biome during the MIS 11.3 interglacial and 
represents a significant northeastward shift in its modern distribution (Lozhkin and Anderson, 2013). The biome analysis (Fig. 5b) assigns two pollen assemblages to the cool conifer forest (COCO) biome, which corresponds to the appearance of Corylus (cool temperate broadleaf genus) pollen in the MIS 11.3 assemblage. However, the discontinuous presence of this pollen taxon in the El'gygytgyn record has been interpreted as long-distance transport from southern regions, and not indicative of the establishment of the shrub near the lake (Lozhkin and Anderson, 2013). Conventional interpretation of the pollen diagram suggests that shrub tundra did not disappear completely when boreal evergreen coniferous forest was widespread, but rather that tundra likely was restricted to higher elevations (Lozhkin and Anderson, 2013). The latter conclusion is in line with the relatively high biome scores for TUND during the MIS 11.3 (Fig. 5a) and explains the reconstructed re-establishment of the tundra biome in the region during the later part of MIS 11.

\subsection{The interval including the MIS 31 interglacial ( 1092-1057 ka ago)}

The biome reconstruction for $\sim 1092-1057 \mathrm{ka}$ ago (Fig. 6) provides another example of a long interglacial interval ( 1084-1062 ka ago; i.e., $22 \mathrm{ka}$ ) dominated by the TAIG biome. The onset of interglacial conditions occurs after $\sim 1088 \mathrm{ka}$ ago, when STEP biome scores decrease abruptly to ones similar to Holocene levels. At this time, forest biome scores increase (Fig. 6a), although TUND still remains as a dominant vegetation type (Fig. 6b). Extremely low STEP scores characterize the interval between $\sim 1086$ and $1068 \mathrm{ka}$ ago (Fig. 6a), while the maximum spread of boreal trees occurs from $\sim 1078$ to $1066 \mathrm{ka}$ ago (Fig. $6 \mathrm{c}$ ) or during the middle part of MIS 31 (Fig. 6d). A turn to colder and drier environments is evident by the end of MIS 31. However, TUND replaces TAIG as the dominant vegetation type only $\sim 1062 \mathrm{ka}$ ago, marking the transition to MIS 30 (Fig. 6d).

A dominance of boreal tree and shrub taxa, including Abies (fir), Picea, Larix, Pinus, Betula and Alnus, characterizes the MIS 31 interglacial pollen record. Low percentages of the cool temperate broad-leaved deciduous tree/shrub taxa (e.g., Corylus, Carpinus, Acer (maple) and Quercus) also appear (Lozhkin and Anderson, 2013). The influence of these more temperate taxa on the biome reconstructions is reflected in the dominance of COCO scores in three levels at the beginning and at the end of the interglacial (Fig. 6b), an interval otherwise dominated by TAIG. According to the biome model and present-day bioclimatic limits for boreal and temperate taxa, COCO requires warmer summer and winter conditions than TAIG (Prentice et al., 1992; Kaplan, 2001). A discontinuous appearance of COCO during the initial and final stages of the interglacial likely indicates long-distance transport of the temperate pollen taxa from warmer regions. Lozhkin and Anderson (2013) also interpreted these warm taxa as being exotic contributors to the MIS 31 record. The

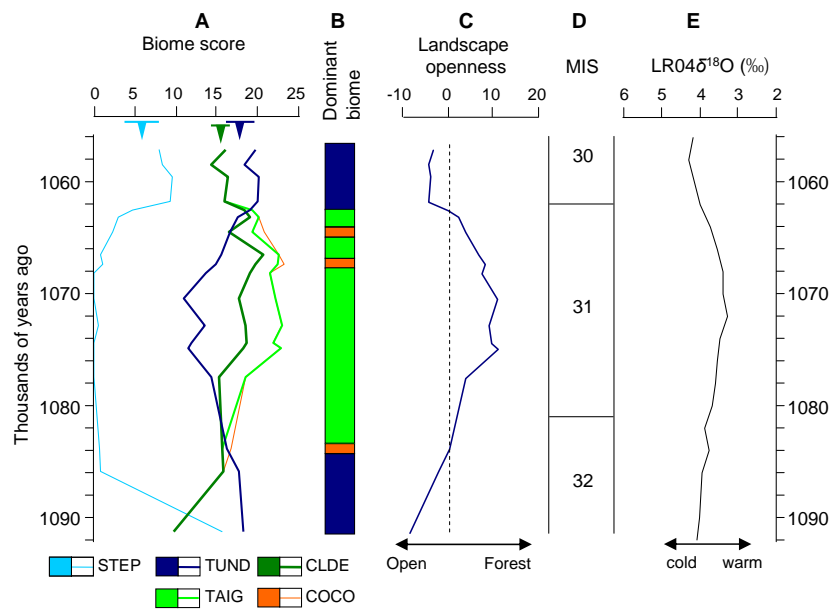

Fig. 6. Summary of paleoenvironmental trends between $\sim 1092$ and $\sim 1057 \mathrm{ka}$ ago showing the (A) time series of individual biomes (triangles indicate the modern mean score of each respective biome; horizontal bars indicate the $95 \%$ uncertainty ranges); (B) dominant biomes; (C) characteristic of landscape openness calculated as the difference between the maximum score of forest biomes (MSFB) and the maximum score of open biomes (MSOB) at each level; and (D) marine isotope stage (MIS) boundaries and (E) stack of 57 globally distributed benthic $\delta^{18} \mathrm{O}$ records (after Lisiecki and Raymo, 2005). Biome names are abbreviated as follows: STEP cold steppe, TUND - tundra, CLDE - cold deciduous forest, TAIG - taiga, and $\mathrm{COCO}$ - cool conifer forest. Note that TAIG and COCO biomes are not present in the modern regional vegetation, and therefore their score is identical to CLDE in the modern spectra (see Prentice et al., 1996, and Sect. 2.3 for explanations).

latter study further suggested that forests that included temperate taxa possibly occurred in closer proximity to Lake El'gygytgyn as compared to today, implying much warmer and wetter than present conditions (Melles et al., 2012; Fig. $7 \mathrm{c}$ and d).

\subsection{The late Pliocene and early Pleistocene interval ( 3562-2200 ka ago)}

Results of the biome reconstructions (Fig. 7a) indicate that the late Pliocene-early Pleistocene can be characterized by six vegetation types. The four biomes representing forest are composed of either boreal (i.e., CLDE and TAIG) or a mixture of boreal and temperate tree taxa (i.e., COCO and cool mixed (COMX) forest). The other two biomes (i.e., TUND and STEP) represent open vegetation dominated by boreal and/or arctic herb and shrub communities. The biome reconstruction (Fig. 7a) and landscape openness (Fig. 7b) reflect millennial-scale vegetation changes in the Lake El'gygytgyn region that correspond well with shifts in global climate represented by alternating cold and warm marine isotope stages (Fig. 7e).

Biome reconstructions demonstrate a trend in the regional vegetation history, which suggests a step-like transition from 
A

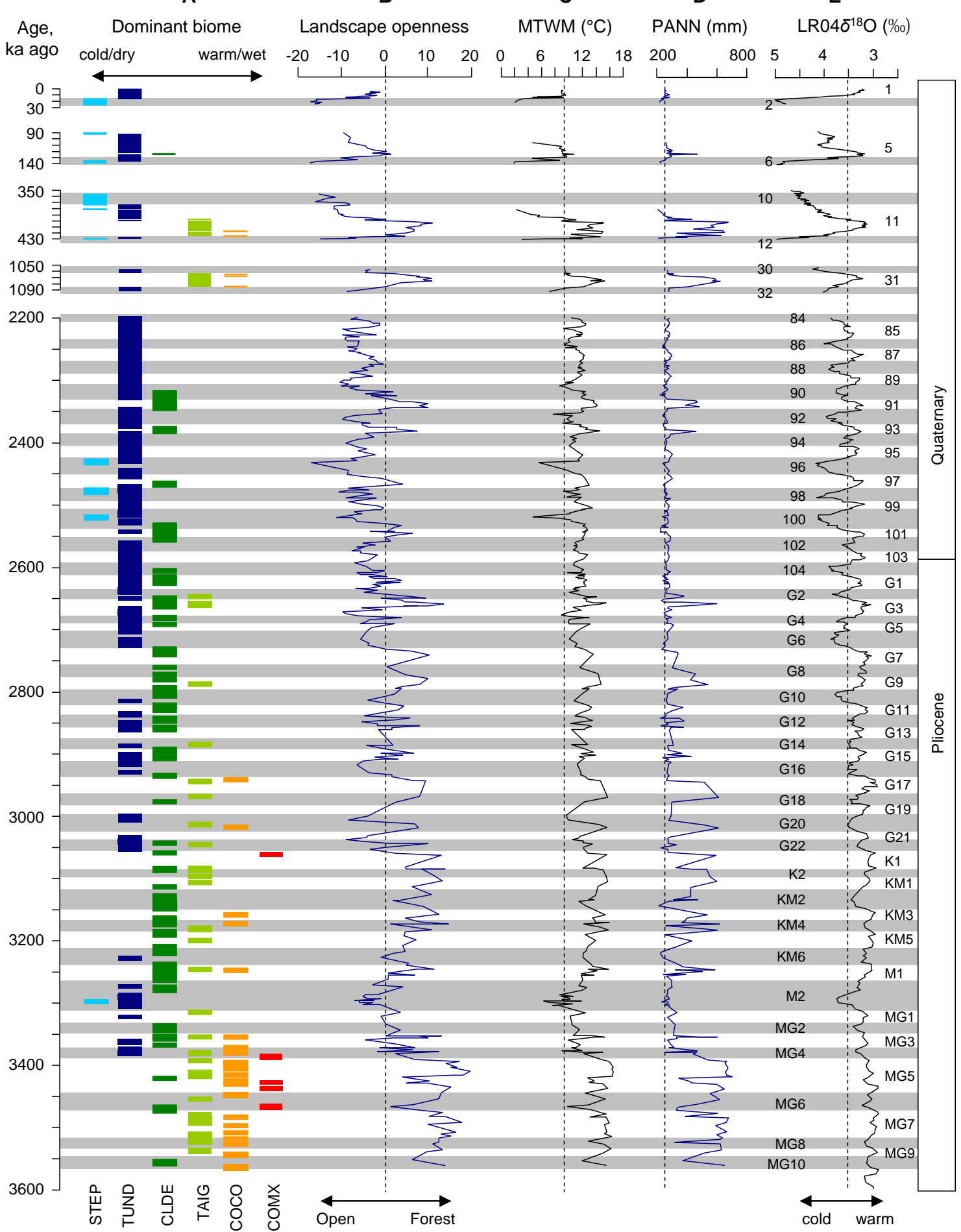

Fig. 7. Summary of paleoenvironmental trends between $\sim 3580$ and $\sim 2200$ ka ago showing the (A) time series of the dominant vegetation types (biomes); (B) characteristic of landscape openness calculated as the difference between the maximum score of the forest biomes (MSFB) and the maximum score of the open biomes (MSOB) at each level; (C) pollen-based reconstructions of the mean temperature of the warmest month; (D) pollen-based reconstructions of mean annual precipitation (after Melles et al., 2012; Brigham-Grette et al., 2013); and (E) Pliocene-Pleistocene stack of 57 globally distributed benthic $\delta^{18} \mathrm{O}$ records with marine isotope stage (MIS) numbers (after Lisiecki and Raymo, 2005). Grey and white bands indicate cold and warm marine isotope stages, respectively. Biome names are abbreviated as follows: STEP - cold steppe, TUND - tundra, CLDE - cold deciduous forest, TAIG - taiga, COCO - cool conifer forest, and COMX - cool mixed forest. 
generally warmer/wetter environments of the mid- to late Pliocene towards colder/drier environments of the early Pleistocene. The COMX and COCO biomes (Fig. 7a) consist of boreal and temperate conifers with a mix of temperate broad-leaved trees and shrubs (Table 1). They are particularly noticeable in the lower part of the record prior to MIS G16 (i.e., older than $2937 \mathrm{ka}$ ago), whereas TUND predominance becomes a prominent feature beginning in MIS G6 (i.e., since $2730 \mathrm{ka}$ ago). The biome results indicate the study area supported a noticeable tree population during most of the interval prior to $\sim 2730 \mathrm{ka}$ ago, while a generally open landscape became a common feature after that time (Fig. 7b). The biomization further suggests that the transition from mostly forested to mostly open landscape was not gradual and that the regional vegetation responded rapidly to the warmer and colder global climate oscillations seen in the marine isotopic records (Fig. 7e). Biomes characteristic of open landscapes do appear prior to $\sim 2730 \mathrm{ka}$ ago. For example, TUND is noted as early as $\sim 3379-3378 \mathrm{ka}$ ago within MIS MG4 (Fig. 7a). The cold- and drought-tolerant STEP biome is first evident in the reconstruction $\sim 3298 \mathrm{ka}$ ago during the otherwise TUND-dominated MIS M2 ( 3312-3264 ka ago). Thus, the generally warm Pliocene experienced several cool intervals prior to $\sim 2800 \mathrm{ka}$ ago as shown by TUND dominance (Fig. 7a) in the regional vegetation.

The lower $216 \mathrm{~m}$ of lacustrine sediments (Andreev et al., 2013) provides the most complete terrestrial pollen record of the late Pliocene and early Pleistocene from the Siberian Arctic. Thus, the Lake El'gygytgyn record provides a strong basis for qualitative interpretations of the paleoenvironments (see Andreev et al., 2013) and for reconstructions of past biomes (Fig. 7a and b) and climate (Brigham-Grette et al., 2013; Fig. 7c and d).

Prior to $\sim 3350 \mathrm{ka}$ ago, the pollen assemblages indicate the presence of a forest dominated by spruce, larch, fir, and hemlock with lesser amounts of other boreal and temperate taxa (Andreev et al., 2013). The biome-based interpretation suggests the presence of COCO and COMX forests. Deciduous Quercus is one of the indicator taxa in the El'gygytgyn pollen record that influences the reconstruction of cool mixed forest as Quercus belongs to the temperate deciduous broad-leaved tree/shrub plant functional type (Prentice et al., 1996). In the BIOME global vegetation model, the presence of temperate deciduous broad-leaved arboreal taxa requires the minimum MTCM to be higher than $-15^{\circ} \mathrm{C}$ (Prentice et al., 1992). However, this model-based hypothesis contradicts the modern distribution pattern of temperate deciduous broad-leaved woody taxa (e.g., Quercus mongolica or Mongolian oak), which grow today in southern areas of the Russian Far East (Mokhova et al., 2009), which experiences much colder winter temperatures (minimum MTCM values going down to $-26^{\circ} \mathrm{C}$ ) than allowed by the model. Mokhova et al. (2009) suggested that sufficiently warm summer temperatures combined with high snow accumulation may outweigh the negative influence of low winter temperatures on the temperate broad-leaved tree and shrub taxa. However, it should be acknowledged that the model does not attempt to simulate the distribution of individual taxa, particularly those with unusual adaptations to cold or snow.

Reviewing quantitative reconstructions based on terrestrial proxies from the Arctic, summer temperature (MTWM) remains the most confidentially reconstructed climate variable (e.g., Andreev et al., 2004, 2011; Kienast et al., 2011; Brigham-Grette et al., 2013). Reconstructed values for mean temperature of the coldest month (MTCM) have larger statistical errors and broader uncertainty ranges (Melles et al., 2012) as compared to MTWM. However, the MTCM reconstruction suggests the predominance of relatively warm winter temperatures (i.e., above $-26^{\circ} \mathrm{C}$ ) prior to $\sim 3380 \mathrm{ka}$ ago (Brigham-Grette et al., 2013) in line with qualitative interpretations of the pollen record (Andreev et al., 2013; Brigham-Grette et al., 2013) and biome reconstruction results (Fig. 7a).

The pollen records and biome reconstructions suggest that vegetation changes occurred in several steps (Fig. 7a and b). For example, shifts in the composition of boreal forest happen first with the loss of temperate and then later boreal evergreen conifers, followed by transitions from forested habitats to treeless, shrubby and finally herbaceous environments. Estimates of the MTCM, based on changes in the pollen assemblages, suggest predominantly cold winters since $\sim 2940 \mathrm{ka}$ ago, but especially since $\sim 2730 \mathrm{ka}$ ago (Brigham-Grette et al., 2013). Such winter coolness has important implications for arctic vegetation-climate feedbacks (Levis et al., 1999), such as the expansion of tundra causing increased land surface albedo (thus lowering air temperatures), especially during snow-covered months.

Results of the palynological research and synthesis of the published proxy data from regions of northern Asia and northern North America for the late Pliocene/early Pleistocene presented in the current special issue (see Andreev et al., 2013, for details and references) offer an excellent opportunity for evaluating results of the pollen-based biome reconstruction presented here. For example, numerous coprophilous fungal spores revealed in the pollen samples within the Mammoth subchron (MIS M2) suggest open landscape and the presence of grazing animals around the lake, a conclusion that agrees with the pollen-based interpretations. Peaks in green algae (Botryococcus) colonies appear well within the intervals for which pollen-inferred reconstructions suggest relatively dry vegetation and climate.

\subsection{Data-model comparison}

In the case of Lake El'gygytgyn, there is an opportunity to compare results from the biome reconstructions obtained in the current study (Fig. 7a and b) to (1) the recently published reconstructions of temperature (Fig. 7c) and atmospheric precipitation (Fig. 7d) derived from the El'gygytgyn pollen records using the best modern analog 
(BMA) approach (Melles et al., 2012; Brigham-Grette et al., 2013); and (2) additional paleoenvironmental reconstructions from other long-term records (e.g., Lisiecki and Raymo, 2005, Fig. 7e). Approaches that have proved useful for interpreting the El'gygytgyn record involve the application of biome reconstruction and BMA. Both methods have their own set of assumptions and shortcomings. For example, the biomization method provides only rough climate information (for bioclimatic limits of different PFTs and biomes, see Prentice et al., 1996 and Kaplan et al., 2003). However, it is "closer" to the actual vegetation and does not suffer as much from the no-analog problem that faces more quantitative approaches (Prentice et al., 1996). Although the modern analog technique may be somewhat limited by analogrelated issues, this technique has provided robust climate reconstructions, when good analogs exist (e.g., Guiot, 1990; Jackson and Williams, 2004; Tarasov et al., 2007a). One of the main advantages of the "biomization" approach, which allows paleovegetation to be reconstructed from either climate or pollen data (Prentice et al., 1992, 1996), is that in both cases the main vegetation types (biomes) are uniformly defined. This consistency is of key importance, because it allows the results of model simulations to be directly compared with the pollen-based biome reconstructions. Melles et al. (2012) reported on GCM (General Circulation Model) experiments that included an interactive vegetation component (using GENESIS 3.0 coupled to BIOME4). This paper examined the MIS 1, MIS 5.5, MIS 11.3 and MIS 31 interglacial intervals with a geographic focus on the Arctic. The results of the climate model simulations when converted to vegetation maps show a striking similarity to the pollen-based vegetation reconstructions presented here. Thus, shrub tundra appears around Lake El'gygytgyn in the modern (preindustrial control) and $9 \mathrm{ka}$ runs, whereas deciduous taiga (i.e., CLDE) is simulated in the lake vicinity during the early Holocene thermal optimum. CLDE also is simulated near Lake El'gygytgyn during the warmest phase of the MIS 5.5 interglacial. Evergreen taiga (i.e., TAIG) predominates during MIS $11.3(\sim 410 \mathrm{ka}$ ago $)$, and a mixture of TAIG and CLDE vegetation is simulated for the MIS 31 interglacial ( $\sim 1072 \mathrm{ka}$ ago), corresponding to the timing of peak summer warmth (Melles et al., 2012). Both model simulations and proxy-based reconstructions suggest that MIS 11.3 was the warmest and longest interglacial of the past million years (Melles et al., 2012).

More recently Kleinen et al. (2013) examined climate and vegetation dynamics during the MIS 11.3 using a model of intermediate complexity (CLIMBER2-LPJ; see Kleinen et al., 2010, 2011, for model details and references) and a second comprehensive general circulation model (CCSM3; see Yeager et al., 2006, for a detailed description of the model). Results of the climate modeling were then converted into maps of potential natural vegetation using BIOME4 (a coupled carbon and water flux model that predicts the steady-state vegetation distribution, structure, and biogeochemistry, taking into account interaction between these effects; Kaplan, 2001; Kaplan et al., 2003) for the four selected time slices within MIS 11.3. For comparison, the modern (preindustrial) biome distribution was also simulated using an early 20th century climatology. In agreement with the pollen data and pollen-based biome reconstruction, enhanced tree cover occurred 416 and $410 \mathrm{ka}$ ago, although the tree cover was more pronounced in CCSM3 as compared to CLIMBER2-LPJ. Modeling shows (dwarf) shrub tundra as the preindustrial biome, which turns into high shrub tundra and even taiga forest in some locations 416 and $410 \mathrm{ka}$ ago. The modeling results indicate a dwarf shrub tundra biome and a reduction of woody vegetation cover at 400 and $394 \mathrm{ka}$ ago. These results indicate that there is general agreement about the timing of the interglacial-glacial transition in both models (Kleinen et al., 2013).

Climate and biome models also have been used in a set of sensitivity experiments that focus on the earlier part of the Lake El'gygytgyn record to test the response of temperature and precipitation to the buildup of Northern Hemisphere ice sheets (Brigham-Grette et al., 2013). Although results are preliminary, the simulations indicate a drying caused by the presence of large Northern Hemisphere ice sheets. This simulated PANN decrease and the simulated magnitude in MTCM are similar to ones determined in the proxybased biome and climate reconstructions after $\sim 2900 \mathrm{ka}$ ago (Fig. 7). These results, while not definitive, suggest the timeaveraged presence of large Northern Hemisphere ice sheets contributed to the marked drying in the Lake El'gygytgyn record after $\sim 2730 \mathrm{ka}$ ago (Brigham-Grette et al., 2013).

Correlations between the reconstructed MTWM values (Fig. 7c) and trends in the benthic marine isotope stack record (Fig. 7e) were observed by Brigham-Grette et al. (2013) and are also found with the pollen-based biome reconstruction presented here (Fig. 7). The similarities between reconstructions underscore the importance of the global systematic controls that link colder summer temperatures at Lake El'gygytgyn with oceanic proxies of temperature, global ice volume, and sea level (Brigham-Grette et al., 2013).

\section{Conclusions}

The pollen-based biome reconstruction from Lake El'gygytgyn provides a record of climate-driven vegetation change that can be more easily compared with qualitative or quantitative proxy-based climate reconstructions and simulation results from vegetation and climate models. As work progresses with the El'gygytgyn sediments, the temporal resolution of the record will be substantially improved as future studies focus on specific intervals or questions of interest determined by the coarse-resolution analyses, thereby providing additional details to the observed 
shifts in climate and vegetation and opportunities for further applications of modeling and biome/analog techniques.

The objectively generated biome reconstruction from Lake El'gygytgyn is useful for a wide range of paleoenvironmental applications (e.g., data-model comparisons), and they overcome some interpretive difficulties associated with more qualitative approaches. Conventional pollen diagrams contain a great amount of site-specific paleoecological information, and their interpretation requires extensive knowledge of the regional plant ecology and taxonomy. This information often is known primarily by paleobotanists, making pollen diagrams a difficult interpretive tool for other earth scientists. Furthermore, pollen percentages illustrated in diagrams are not directly comparable to climate/vegetation model output, output that is valuable in understanding a variety of earth systems, including atmosphere-biosphere feedbacks. Moreover, comparing spatial and temporal changes in the pollen assemblages among numerous sites and across broad regions is a challenge unless the pollen data are integrated in a systematic manner. The biome reconstruction approach allows diverse pollen data to be compiled more easily within a wellorganized analytical framework. In addition to pollen diagrams, the presentation of results as biomes yields a more understandable format for a majority of geoscientists. The biome approach, although also dependent on understanding ecological relationships, provides a more objectively defined set of natural vegetation types in contrast to the traditional qualitative interpretations. The use of a common set of climatically defined vegetation types in the pollen-based reconstruction and in the model simulations facilitates data-model comparisons. Data-model comparison is beneficial because it (1) allows more accurate evaluation of the climate models and of model output, (2) justifies the selection of models with a better predictive potential, and (3) helps improve knowledge of the past earth system development at the global and regional scales.

The current study provides time series of the pollen-based reconstructed biomes and qualitative evaluation of landscape openness between $\sim 3562$ and $\sim 2200 \mathrm{ka}$ ago and through four glacial-interglacial cycles within the last $\sim 1090 \mathrm{ka}$. These results illustrate the timing and nature of the changes that transformed a predominantly forested Pliocene Siberian Arctic ecosystem into a largely forest-free environment, as seen during the early and late Pleistocene. The results also confirm the earlier reported stepwise temperature decline leading to the onset of Northern Hemisphere glacial cycles. Not only does the El'gygytgyn pollen record improve understanding of the Pliocene-Pleistocene transition, it also illustrates the variability within Pleistocene warm intervals. The middle Pleistocene, in particular, provides examples of long interglacial intervals dominated by taiga, and indicates the extraordinary character of the MIS 31 and MIS 11.3 interglacials.

Biome reconstruction does not rely on transfer functions established from modern pollen-vegetation data sets and, therefore, complements the published climate reconstructions obtained using the best modern analog method. The results also help to verify the ability of modern coupled climate-vegetation models to simulate past climate and vegetation dynamics in the region. Detailed modeling and analysis of the effect of Northern Hemisphere ice sheets, vegetation, and sea-ice feedbacks on the regional environments around Lake El'gygytgyn, particularly during the "early" intervals of extreme cold (i.e., during MIS M2, G16, G6) and during the "late" intervals of extreme warmth (i.e., during MIS 31 and 11.3), remain the subject of future work.

Acknowledgements. Funding for the Lake El'gygytgyn Project was provided by the International Continental Scientific Drilling Program (ICDP), the US National Science Foundation (NSF), the German Federal Ministry of Education and Research (BMBF), Alfred Wegener Institute (AWI) and GeoForschungsZentrum Potsdam (GFZ), the Russian Academy of Sciences Far East Branch (RAS FEB), the Russian Foundation for Basic Research (RFBR), and the Austrian Federal Ministry of Science and Research (BMWF). The work of P. E. Tarasov is funded via the DFG Heisenberg Program (TA 540/5). The palynological analysis of Quaternary sediments was supported by grants to A. V. Lozhkin from the RAS FEB (12-III-A-09-198, 12-II-CO-08-024), RFBR (12-05-00286a), and the Civilian Research and Development Foundation (RUG1-2987-MA-10). T. V. Matrosova, E. F. Gorodnichaya, T. B. Solomatkina, and Yu. A. Korzun provided the palynological data for MIS 31 and younger sediments, including modern surface samples.

Edited by: D.-D. Rousseau

\section{References}

Alpat'ev, A. M., Arkhangel'skii, A. M., Podoplelov, N. Y., and Stepanov, A. Y.: Fizicheskaya geografiya SSSR (Aziatskaya chast'), Vysshaya Shkola, Moscow, p. 359, 1976.

Anderson, P. M., Lozhkin, A. V., Belaya, B., and Stetsenko, T.: Modern spore-pollen spectra from the mountain regions of the Kolyma and Indigirka rivers from lacustrine sediments, in: Quaternary Paleogeography of Beringia, edited by: Simakov, K., NEISRI, FEB, RAS, Magadan, Russia, 28-39, 2002.

Andreev, A. A., Tarasov, P. E., Klimanov, V. A., Melles, M., Lisitsyna, O. M., and Hubberten, H.-W.: Vegetation and climate changes around the Lama Lake, Taymyr Peninsula, Russia during the Late Pleistocene and Holocene, Quatern. Int., 122, 69-84, 2004.

Andreev, A. A., Schirrmeister, L., Tarasov, P. E., Ganopolski, A., Brovkin, V., Siegert, Ch., Wetterich, S., and Hubberten, H.-W.: Vegetation and climate history in the Laptev Sea region (Arctic Siberia) during Late Quaternary inferred from pollen records, Quaternary Sci. Rev., 30, 2182-2199, 2011.

Andreev, A. A., Morozova, E., Fedorov, G., Schirrmeister, L., Bobrov, A. A., Kienast, F., and Schwamborn, G.: Vegetation history of central Chukotka deduced from permafrost paleoenvironmental records of the El'gygytgyn Impact Crater, Clim. Past, 8, 1287-1300, doi:10.5194/cp-8-1287-2012, 2012. 
Andreev, A. A., Tarasov, P. E., Wennrich, V., Raschke, E., Herzschuh, U., Nowaczyk, N. R., Brigham-Grette, J., and Melles, M.: Late Pliocene and early Pleistocene environments of the north-eastern Russian Arctic inferred from the Lake El'gygytgyn pollen record, Clim. Past Discuss., 9, 4599-4653, doi:10.5194/cpd-9-4599-2013, 2013.

Bezrukova, E. V., Tarasov, P. E., Solovieva, N., Krivonogov, S. K., and Riedel, F.: Last glacial-interglacial vegetation and environmental dynamics in southern Siberia: Chronology, forcing and feedbacks, Palaeogeogr. Palaeocl., 296, 185-198, 2010.

Binney, H. A., Willis, K. J., Edwards, M. E., Bhagwat, S. A., Anderson, P. M., Andreev, A. A., Blaauw, M., Damblon, F., Haesaerts, P., Kienast, F., Kremenetski, K. V., Krivogonov, S. K., Lozhkin, A. V., MacDonald, G. M., Novenko, E. Y., Oksanen, P., Sapelko, N. V., Väliranta, M., and Vazhenina, L.: The distribution of late-Quaternary woody taxa in northern Eurasia: evidence from a new macrofossil database, Quaternary Sci. Rev., 28, 2445-2464, 2009.

Brigham-Grette, J., Melles, M., Minyuk, P., Andreev, A., Tarasov, P., DeConto, R., Koenig, S., Nowaczyk, N., Wennrich, V., Rosén, P., Haltia-Hovi, E., Cook, T., Gebhardt, C., Meyer-Jacob, C., Snyder, J., and Herzschuh, U.: Pliocene warmth, polar amplification, and stepped Pleistocene cooling recorded in NE Arctic Russia, Science, 340, 1421-1427, 2013.

Cheng, H., Edwards, R. L., Broecker, W. S., Denton, G. H., Kong, X., Wang, Y., Zhang, R., and Wang, X.: Ice age terminations, Science, 326, 248-252, 2009.

Edwards, M. E., Anderson, P. M., Brubaker, L. B., Ager, T. A., Andreev, A. A., Bigelow, N. H., Cwynar, L. C., Eisner, W. R., Harrison, S. P., Hu, F.-S., Jolly, D., Lozhkin, A. V., MacDonald, G. M., Mock, C. J., Ritchie, J. C., Sher, A. V., Spear, R. W., Williams, J. W., and Yu, G.: Pollen-based biomes for Beringia 18,000, 6000 and $0{ }^{14} \mathrm{C}$ yr BP, J. Biogeogr., 27, 521-554, 2000.

Edwards, M. E., Brubaker, L. B., Lozhkin, A. V., and Anderson, P. M.: Structurally novel biomes: a response to past warming in Beringia, Ecology, 86, 1696-1703, 2005.

Faegri, K. and Iversen, J.: Textbook of pollen analysis, 4th Edn., edited by: Faegri, K., Kaland, P. E., and Krzywinski, K., John Wiley and Sons, Chichester, p. 328, 1989.

Gotanda, K., Nakagawa, T., Tarasov, P., Kitagawa, J., Inoue, Y., and Yasuda, Y.: Biome classification from Japanese pollen data: application to modern-day and late Quaternary samples, Quaternary Sci. Rev., 21, 647-657, 2002.

Gotanda, K., Nakagawa, T., Tarasov, P. E., and Yasuda, Y.: Disturbed vegetation reconstruction using the biomization method from Japanese pollen data: Modern and Late Quaternary samples, Quatern. Int., 184, 56-74, 2008.

Grimm, E. C.: TILIA 2.0 Version b.4 (Computer Software), Illinois State Museum, Research and Collections Center, Springfield, 1993.

Grimm, E. C.: TGView, Illinois State Museum, Research and Collections Center, Springfield, 2004.

Guiot, J.: Methodology of the last climatic cycle reconstruction from pollen data, Palaeogeogr. Palaeocl., 80, 49-69, 1990.

Guiot, J. and Goeury, C.: PPPBASE, a software for statistical analysis of paleoecological and paleoclimatological data, Dendrochronologia, 14, 295-300, 1996.
Guiot, J., Torre, F., Cheddadi, R., Peyron, O., Tarasov, P., Jolly, D., Kaplan, J. O.: The climate of the Mediterranean Basin and of Eurasia of the Last Glacial Maximum as reconstructed by inverse vegetation modelling and pollen data, Ecol. Mediter., 25, 193 204, 1999.

Haltia, E. M. and Nowaczyk, N. R.: Magnetostratigraphy of sediments from Lake El'gygytgyn ICDP Site 5011-1: paleomagnetic age constraints for the longest paleoclimate record from the continental Arctic, Clim. Past Discuss., 9, 5077-5122, doi:10.5194/cpd-9-5077-2013, 2013.

Jackson, S. T. and Williams, J. W.: Modern analogs in Quaternary paleoecology: here today, gone yesterday, gone tomorrow?, Annu. Rev. Earth Planet. Sci., 32, 495-537, 2004.

Kaplan, J. O.: Geophysical Applications of Vegetation Modelling, Lund University, Lund, 2001.

Kaplan, J. O., Bigelow, N. H., Prentice, I. C., Harrison, S. P., Bartlein, P. J., Christensen, T. R., Cramer, W., Matveyeva, N. V., McGuire, A. D., Murray, D. F., Razzhivin, V. Y., Smith, B., Walker, D. A., Anderson, P., Andreev, A. A., Brubaker, L. B., Edwards, M. E., and Lozhkin, A. V.: Climate change and arctic ecosystems: 2. Modeling, paleodata-model comparisons, and future projections, J. Geophys. Res., 108, 8171, doi:10.1029/2002JD002559, 2003.

Kienast, F., Wetterich, S., Kuzmina, S., Schirrmeister, L., Andreev, A., Tarasov, P. E., Nazarova, L., Kossler, A., Frolova, L., and Kunitsky, V. V.: Paleontological records indicate the occurrence of open woodlands in a dry inland climate at the present-day Arctic coast in western Beringia during the last interglacial, Quaternary Sci. Rev., 30, 2134-2159, 2011.

Kleinen, T., Brovkin, V., von Bloh, W., Archer, D., and Munhoven, G.: Holocene carbon cycle dynamics, Geophys. Res. Lett., 37, L02705, doi:10.1029/2009GL041391, 2010.

Kleinen, T., Tarasov, P., Brovkin, V., Andreev, A., and Stebich, M.: Comparison of modeled and reconstructed changes in forest cover through the past 8000 years: Eurasian perspective, Holocene, 5, 723-734, doi:10.1177/0959683610386980, 2011.

Kleinen, T., Hildebrandt, S., Prange, M., Rachmayani, R., Müller, S., Bezrukova, E., Brovkin, V., and Tarasov, P. E.: The climate and vegetation of Marine Isotope Stage 11 - model results and proxy-based reconstructions at global and regional scale, Quatern. Int., in press, 2013.

Laskar, J., Robutel, P., Joutel, F., Gastineau, M., Correia, A. C. M., and Levrard, B.: A long-term numerical solution for the insolation quantities of the Earth, Astron. Astrophys., 428, 261-285, 2004.

Layer, P. W.: Argon-40/argon-39 age of the El'gygytgyn impact event, Chukotka, Russia, Meteorol. Planet. Sci., 35, 591-599, 2000.

Levis, S., Foley, J. A., and Pollard, D.: Potential high-latitude vegetation feedbacks on $\mathrm{CO}_{2}$-induced climate change, Geophys. Res. Lett., 26, 747-750, 1999.

Lisiecki, L. E. and Raymo, M. E.: A Pliocene-Pleistocene stack of 57 globally distributed benthic $\delta^{18} \mathrm{O}$ records, Paleoceanography, 20, PA1003, doi:10.1029/2004PA001071, 2005.

Lozhkin, A. V.: Geochronology of late Quaternary events in northeastern Russia, Radiocarbon, 35, 429-433, 1993.

Lozhkin, A. V. and Anderson, P. M.: The last interglaciation in northeast Siberia, Quaternary Res., 43, 147-158, 1995. 
Lozhkin, A. V. and Anderson, P. M.: Vegetation responses to interglacial warming in the Arctic: examples from Lake El'gygytgyn, Far East Russian Arctic, Clim. Past, 9, 1211-1219, doi:10.5194/cp-9-1211-2013, 2013.

Lozhkin, A. V., Anderson, P. M., Vartanyan, S., Brown, T., Belaya, B., and Kotov, A.: Reconstructions of late Quaternary paleo-environments and modern pollen data from Wrangel Island (northern Chukotka), Quaternary Sci. Rev., 20, 217-233, 2001.

Lozhkin, A. V., Anderson, P. M., Matrosova, T., and Minyuk, P.: The pollen record from El'gygytgyn Lake: implications for vegetation and climate histories of northern Chukotka since the late middle Pleistocene, J. Paleolimnol., 37, 135-153, 2007.

MacDonald, G. M., Velichko, A. A., Kremenetski, C. V., Borisova, O. K., Goleva, A. A., Andreev, A. A., Cwynar, L. C., Riding, R. T., Forman, S. L., Edwards, T. W. D., Aravena, R., Hammarlund, D., Szeicz, J. M., and Gattaulin, V. N.: Holocene treeline history and climate change across Northern Eurasia, Quaternary Res., 53, 302-311, 2000.

Marchant, R., Boom, A., Hooghiemstra, H.: Pollen-based biome reconstructions for the past $450000 \mathrm{yr}$ from the Funza-2 core, Colombia: comparisons with model-based vegetation reconstructions, Palaeogeogr. Palaeocl., 77, 29-45, 2002.

Marchant, R., Berrìo, J. C., Behling, H., Boom, A., Hooghiemstra, H.: Colombian dry moist forest transitions in the Llanos Orientales - A comparison of model and pollen-based biome reconstructions, Palaeogeogr. Palaeocl., 234, 28-44, 2006.

Martrat, B., Grimalt, J. O., Shackleton, N. J., de Abreu, L., Hutterli, M. A., and Stocker, T. F.: Four climate cycles of recurring deep and surface water destabilizations on the Iberian Margin, Science, 317, 502-507, 2007.

Matrosova, T. V.: Klimat i rastitel'nost' Anadyrskogo ploskogor'ya za poslednie 350 tys. let (palinologicheskaya kharakteristika osadkov oz. El'gygytgyn), unpublished PhD Thesis, Magadan, p. 197, 2009.

Melles, M., Brigham-Grette, J., Minyuk, P. S., Nowaczyk, N. R., Wennrich, V., DeConto, R. M., Anderson, P. M., Andreev, A. A., Coletti, A., Cook, T. L., Haltia-Hovi, E., Kukkonen, M., Lozhkin, A. V., Rosén, P., Tarasov, P. E., Vogel, H., and Wagner, B.: 2.8 Million years of Arctic climate change from Lake El'gygytgyn, NE Russia, Science, 337, 315-320, 2012.

Mokhova, L., Tarasov, P. E., Bazarova, V., and Klimin, M.: Quantitative biome reconstruction using modern and late Quaternary pollen data from the southern part of the Russian Far East, Quaternary Sci. Rev., 28, 2913-2926, 2009.

Müller, S., Tarasov, P. E., Andreev, A. A., and Diekmann, B.: Late Glacial to Holocene environments in the present-day coldest region of the Northern Hemisphere inferred from a pollen record of Lake Billyakh, Verkhoyansk Mts, NE Siberia, Clim. Past, 5, 73-84, doi:10.5194/cp-5-73-2009, 2009.

Müller, S., Tarasov, P. E., Andreev, A. A., Tütken, T., Gartz, S., and Diekmann, B.: Late Quaternary vegetation and environments in the Verkhoyansk Mountains region (NE Asia) reconstructed from a 50-kyr fossil pollen record from Lake Billyakh, Quaternary Sci. Rev., 29, 2071-2086, 2010.

New, M., Lister, D., Hulme, M., and Makin, I.: A high-resolution data set of surface climate over global land areas, Clim. Res., 21, $1-25,2002$.
Nolan, M. and Brigham-Grette, J.: Basic hydrology, limnology, and meteorology of modern Lake El'gygytgyn, Siberia, J. Paleolimnol., 37, 17-35, 2007.

Nowaczyk, N. R., Haltia, E. M., Ulbricht, D., Wennrich, V., Sauerbrey, M. A., Rosén, P., Vogel, H., Francke, A., MeyerJacob, C., Andreev, A. A., and Lozhkin, A. V.: Chronology of Lake El'gygytgyn sediments - a combined magnetostratigraphic, palaeoclimatic and orbital tuning study based on multiparameter analyses, Clim. Past, 9, 2413-2432, doi:10.5194/cp-92413-2013, 2013.

Overpeck, J. T., Webb III, T., and Prentice, I. C.: Quantitative interpretation of fossil pollen spectra, dissimilarity coefficients and the method of modern analogs, Quaternary Res., 23, 87-108, 1985.

Peyron, O., Guiot, J., Cheddadi, R., Tarasov, P. E., Reille, M., Beaulieu, J. L., de Bottema, S., and Andrieu, V.: Climatic reconstruction in Europe for 18,000 yr B.P. from pollen data, Quaternary Res., 49, 183-196, 1998.

Prentice, I. C. and Webb III, T.: BIOME 6000: reconstructing global mid-Holocene vegetation patterns from palaeoecological records, J. Biogeogr., 25, 997-1005, 1998.

Prentice, I. C., Cramer, W., Harrison, S. P., Leemans, R., Monserud, R. A., and Solomon, A. M.: A global biome model based on plant physiology and dominance, soil properties and climate, J. Biogeogr., 19, 117-134, 1992.

Prentice, I. C., Guiot, J., Huntley, B., Jolly, D., and Cheddadi, R.: Reconstructing biomes from palaeoecological data: a general method and its application to European pollen data at 0 and $6 \mathrm{ka}$, Clim. Dynam., 12, 185-194, 1996.

Prentice, I. C., Jolly, D., and BIOME 6000 participants: MidHolocene and glacial maximum vegetation geography of the northern continents and Africa, J. Biogeogr., 27, 507-519, 2000.

Rudaya, N., Tarasov, P. E., Dorofeyuk, N., Solovieva, N., Kalugin, I., Andreev, A., Daryin, A., Diekmann, B., Riedel, F., Tserendash, N., and Wagner, M.: Holocene environments and climate in the Mongolian Altai reconstructed from the Hoton-Nur pollen and diatom records: a step towards better understanding climate dynamics in Central Asia, Quaternary Sci. Rev., 28, 540-554, 2009.

Shilo, N. A., Lozhkin, A., Anderson, P. M., Vazhenina, L. N., Glushkova, O. Yu., and Matrosova, T. V.: First data about the expansion of Larix gmelinii (Rupr.) Rupr. in arctic region of Beringia durng the early Holocene, Doklady Akademii Nauk, 422, 1-3, 2008.

Takahara, H., Igarashi, Y., Hayashi, R., Kumon, F., Liew, P.-M., Yamamoto, M., Kawai, S., Oba, T., and Irino, T.: Millennial-scale variability in vegetation records from the East Asian Islands: Taiwan, Japan and Sakhalin, Quaternary Sci. Rev., 29, 2900-2917, 2010.

Tarasov, P. E., Jolly, D., Kaplan, J. O.: A continuous Late Glacial and Holocene record of vegetation changes in Kazakhstan, Palaeogeogr. Palaeocl., 136, 281-292, 1997.

Tarasov, P. E., Cheddadi, R., Guiot, J., Bottema, S., Peyron, O., Belmonte, J., Ruiz-Sanchez, V., Saadi, F. A., and Brewer, S.: A method to determine warm and cool steppe biomes from pollen data; application to the Mediterranean and Kazakhstan Regions, J. Quaternary Sci., 13, 335-344, 1998. 
Tarasov, P. E., Volkova, V. S., Webb III, T., Guiot, J., Andreev, A. A., Bezusko, L. G., Bezusko, T. V., Bykova, G. V., Dorofeyuk, N. I., Kvavadze, E. V., Osipova, I. M., Panova, N. K., and Sevastyanov, D. V.: Last Glacial Maximum biomes reconstructed from pollen and plant macrofossil data from Northern Eurasia, J. Biogeogr., 27, 609-620, 2000.

Tarasov, P. E., Granoszewski, W., Bezrukova, E., Brewer, S., Nita, M., Abzaeva, A., and Oberhänsli, H.: Quantitative reconstruction of the Last Interglacial vegetation and climate based on the pollen record from Lake Baikal, Russia, Clim. Dynam., 25, 625-637, 2005.

Tarasov, P. E., Bezrukova, E., Karabanov, E., Nakagawa, T., Wagner, M., Kulagina, N., Letunova, P., Abzaeva, A., Granoszewski, W., and Riedel, F.: Vegetation and climate dynamics during the Holocene and Eemian interglacials derived from Lake Baikal pollen records, Palaeogeogr. Palaeocl., 252, 440-457, 2007a.

Tarasov, P. E., Williams, J. W., Andreev, A., Nakagawa, T., Bezrukova, E., Herzschuh, U., Igarashi, Y., Müller, S., Werner, K., and Zheng, Z.: Satellite- and pollen-based quantitative woody cover reconstructions for northern Asia: verification and application to late-Quaternary pollen data, Earth Planet. Sc. Lett., 264, 284-298, 2007b.

Tarasov, P. E., Nakagawa, T., Demske, D., Österle, H., Igarashi, Y., Kitagawa, J., Mokhova, L., Bazarova, V., Okuda, M., Gotanda, K., Miyoshi, N., Fujiki, T., Takemura, K., Yonenobu, H., and Fleck, A.: Progress in the reconstruction of Quaternary climate dynamics in the Northwest Pacific: A new modern analogue reference dataset and its application to the 430-kyr pollen record from Lake Biwa, Earth-Sci. Rev., 108, 64-79, 2011.

Tarasov, P. E., Müller, S., Zech, M., Andreeva, D., Diekmann, B., and Leipe, C.: Last glacial vegetation reconstructions in the extreme-continental eastern Asia: Potentials of pollen and nalkane biomarker analyses, Quatern. Int., 290-291, 253-263, 2013.
Texier, D., de Noblet, N., Harrison, S. P., Haxeltine, A., Jolly, D., Joussaume, S., Laarif, F., Prentice, I. C., and Tarasov, P. E.: Quantifying the role of biosphere-atmosphere feedbacks in climate change: coupled model simulations for 6000 years BP and comparison with palaeodata for northern Eurasia and northern Africa, Clim. Dynam., 13, 865-882, 1997.

Treshnikov, A. F.: Atlas of the Arctic, Main Department of Geodesy and Cartography under the Council of Ministers of the USSR, Moscow, 1985.

Vogel, H., Meyer-Jacob, C., Melles, M., Brigham-Grette, J., Andreev, A. A., Wennrich, V., Tarasov, P. E., and Rosén, P.: Detailed insight into Arctic climatic variability during MIS 11c at Lake El'gygytgyn, NE Russia, Clim. Past, 9, 1467-1479, doi:10.5194/cp-9-1467-2013, 2013.

Williams, J. W., Shuman, B. N., Webb III, T., Bartlein, P. J., and Leduc, P. L.: Late Quaternary vegetation dynamics in North America: scaling from taxa to biomes, Ecol. Monogr., 74, 309334, 2004.

Williams, J. W., Tarasov, P., Brewer, S., and Notaro, M.: Late Quaternary variations in tree cover at the northern forest-tundra ecotone, J. Geophys. Res., 116, G01017, doi:10.1029/2010JG001458, 2011.

Yeager, S. G., Shields, C. A., Large, W. G., and Hack, J. J.: The low-resolution CCSM3, J. Climate, 19, 2545-2566, 2006.

Yu, G., Prentice, I. C., Harrison, S. P., and Sun, X.: Pollen-based biome reconstructions for China at 0 and 6000 years, J. Biogeogr., 25, 1055-1069, 1998.

Yu, G., Chen, X., Ni, J., Cheddadi, R., Guiot, J., Han, H., Harrison, S. P., Huang, C., Ke, M., Kong, Z., Li, S., Li, W., Liew, P., Liu, G., Liu, J., Liu, K. B., Prentice, I. C., Qui, W., Ren, G., Song, C., Sugita, S., Sun, X., Tang, L., Van Campo, E., Xia, Y., Xu, Q., Yan, S., Yang, X., Zhao, J., and Zheng, Z.: Palaeovegetation of China: a pollen data based synthesis for the mid-Holocene and last glacial maximum, J. Biogeogr., 27, 635-664, 2000.

Yurtsev, B. A.: Problemy botanicheskoi geografii SeveroVostochnoi Azii, Nauka, Leningrad, p. 159, 1974. 